\title{
1 Excess deaths associated with fine particulate matter in Brazilian cities
}

1 Department of Sanitary and Environmental Engineering, Federal University of Minas Gerais, Belo Horizonte 31270-010, Brazil

2 Department of Environmental Engineering, Federal University of Espírito Santo,

Vitória 29060-970, Brazil

${ }^{3}$ Global Centre for Clean Air Research (GCARE), Department of Civil and Environmental Engineering, Faculty of Engineering and Physical Sciences, University of Surrey, Guildford GU2 7XH, United Kingdom

* Corresponding author: 
13 Abstract: Fine particulate matter $\left(\mathrm{PM}_{2.5} ; \leq 2.5 \mu \mathrm{m}\right.$ in aerodynamic diameter $)$ stands out among all pollutants as more directly responsible for long-term health problems. This work aims to evaluate the public health benefits of improved air quality in Brazil, based on the estimated reduction in mortality from $\mathrm{PM}_{2.5}$, a pollutant commonly related to all causes mortality including non-accidental, cardiovascular, ischemic heart diseases and lung cancer. Annual $\mathrm{PM}_{2.5}$ concentrations were obtained from 50 monitoring stations spread across 24 Brazilian cities between the years 2000 and 2017, which constituted the baseline scenario. The control scenario was represented by the annual $\mathrm{PM}_{2.5}$ guideline values $\left(10 \mu \mathrm{g} \mathrm{m}^{-3}\right)$ of the World Health Organization (WHO). The relationship between the change in baseline and control scenarios with health effects was estimated using the BenMAP-CE program and the application of exposure-response functions. São Paulo city showed the highest number of avoidable deaths, with values ranging from $28,874 \pm 9,769$ and 82,720 $\pm 24,549$ for all causes from 2000 to 2017. In 2009, just three Brazilian cities were monitoring $\mathrm{PM}_{2.5}$. Between $877 \pm 295$ and 2,497 \pm 719 all causes avoidable deaths related to $\mathrm{PM}_{2.5}$ were estimated under the scenario when the WHO guideline was applied. In 2017, the 15 cities with representative annual $\mathrm{PM}_{2.5}$ data account for between $2,378 \pm 801$ and $6,282 \pm 1,818$ avoidable deaths due to all-cause $\mathrm{PM}_{2.5}$ mortality, between $2,974 \pm 376$ and $10,397 \pm 516$ avoidable deaths due non-accidental causes, between $1,373 \pm 230$ and $3,428 \pm 265$ avoidable deaths due cardiovascular disease, between $927 \pm 162$ and $2,514 \pm 156$ avoidable deaths due ischemic heart diseases and the lowest between $101 \pm 45$ and $264 \pm 88$ avoidable deaths due to lung cancer.

Keywords: Fine particles; Health benefits; Avoidable deaths; Monitoring data; Brazil;

Urban centers

\section{Research highlights}

- Brazilian air quality monitoring data from 24 cities were used to estimate avoidable deaths

- Almost $90 \%$ of the annual $\mathrm{PM}_{2.5}$ concentrations in Brazilian cities were higher than WHO guideline

- Large urban centers such as Sao Paulo city obtained higher values of avoidable deaths

- National PM 2.5 standard in Brazil based on WHO guideline could bring health-related benefits 


\section{$44 \quad 1 \quad$ Introduction}

45 Urban populations around the world have increased from $46.5 \%$ in the year 2000 to $54.3 \%$ 46 in 2016, while in Brazil, the urban population reached 85.9\% in 2016 (UN, 2015; The 47 Word Bank, 2018). It is associated with the intensification of urbanization processes resulting in the consumption of fossil fuel, deforestation, burning, generation of waste and the degradation of air quality (McMichael, 2000). Consequently, air pollution has become a public health concern, even when its levels fall short of current legislation

51 (Curtis et al., 2006).

When determining the concentration of a pollutant in the atmosphere, the degree of exposure of the receptors (humans, animals, plants, materials) is measured as the result of the release of this pollutant into the atmosphere from its emission sources and their physical (dispersion) and chemical (chemical reactions) interactions (Seinfeld and Pandis, 2006). Thus, air quality is the product of the interaction between factors such as emissions, topography and weather conditions.

The World Health Organization (WHO) reported air pollution as the biggest health risk, causing approximately 6.5 million excess deaths globally in 2012, which is $11.6 \%$ of all deaths (WHO, 2016a). Among the main causes are the cardiovascular diseases, stroke,

61 chronic obstructive pulmonary disease and lung cancer, in addition to the increased risks 62 of acute respiratory infections (WHO, 2016a). Cohen et al. (2017) reported that fine particulate matter less than $2.5 \mu \mathrm{m}\left(\mathrm{PM}_{2.5}\right)$ was the fifth largest risk factor for mortality in 2015, averaging 4.2 million deaths globally (7.6\% of all deaths), an increase of $20 \%$ in relation to the total deaths in 1990.

In Brazil, Miranda et al. (2012) estimated the number of deaths associated with the excess exposure to $\mathrm{PM}_{2.5}$ for June 2007 to August 2008, based on experimental campaigns in six Brazilian state capitals for adults over 45 years old. São Paulo presented the worst results with 9,700 premature deaths due to long-term exposure. Rio de Janeiro, Belo Horizonte, Porto Alegre and Curitiba added other 3,900 deaths that could be avoidable if the annual $\mathrm{PM}_{2.5}$ concentrations were reduced to the WHO guideline $\left(10 \mu \mathrm{g} \mathrm{m}^{-3}\right)$.

An extensive body of epidemiological research has established a strong association between chronic exposures to $\mathrm{PM}_{2.5}$ and ischemic heart disease (IHD), cardiovascular, 
al., 2004; Laden et al., 2006; Krewski et al., 2009; Crouse et al., 2012; Cesaroni et al., 2013; Bentayeb et al., 2015). The interaction between the sources of pollution and the atmosphere defines the level of air quality, which in turn determines the occurrence of adverse effects of air pollution on its receptors. In the Metropolitan Area of São Paulo, for example, Martins et al. (2017) showed that the probability of higher concentrations for $\mathrm{CO}, \mathrm{NO}, \mathrm{NO}_{2}, \mathrm{PM}_{10}$ and $\mathrm{PM}_{2.5}$ were more frequent during the winter, while $\mathrm{O}_{3}$ episodes occur most frequently during summer. Air quality monitoring aims to provide data to trigger emergency actions during periods of atmospheric stagnation, assess air quality in the light of established limits to protect the health and well-being of people, enable a correct planning of the territory, and monitor trends and changes in air quality due to changes in pollutant emissions.

Exposure to air pollutants is a risk factor for humans and many existing studies that attempt to assess the relationship between air pollution and mortality use pollutant concentration data from air quality monitoring stations (Pope III et al, 2002; Pope et al, 2004; Laden, et al, 2006; Wong et al., 2008; Katanoda et al, 2011; Lepeule et al., 2012; Huang et al., 2012; Thurston et al., 2016). In Brazil, air quality monitoring is still restricted and unsatisfactory in terms of sample history, territorial coverage, number of monitored parameters and representatively in measurements, due to management difficulties and the low number of technicians involved, as well as lack of resources for the purchase and maintenance of equipment and monitoring networks (Brazil, 2014). In addition, the fine particulate matter is not yet nationally legislated.

Until 2017, there were 24 Brazilian cities with $\mathrm{PM}_{2.5}$ monitoring. All these cities were in the southeastern region of Brazil. With measurements beginning in the year 2000 in São Paulo city, the concern with this pollutant is increasing, and an annual increase in the number of $\mathrm{PM}_{2.5}$ monitoring stations is noticed. For the first time, this study performs an assessment of the number of total avoidable deaths attributable to a reduction in $\mathrm{PM}_{2.5}$ concentrations, considering the annual guideline established by the WHO $\left(10 \mu \mathrm{g} \mathrm{m}^{-3}\right)$ for all 24 Brazilian cities during 2000-2017 years with the available monitoring data. These results may be valuable to consider effective strategies to expanding air quality monitoring in Brazil, to improve air quality and for the adoption of a national standard for $\mathrm{PM}_{2.5}$, allowing policymakers to project the population health improvements. 
1062 Materials and methods

$107 \quad 2.1 \quad$ Health Effects

108 The US EPA's Environmental Benefits Mapping and Analysis Program (Community 109 Edition; BenMAP-CE; v.1.3) (Sacks et al., 2018) is used to facilitate the analyses of 110 health effects. The inputs included a shapefile, the incident rates of the cause evaluated, 111 population data, a health impact function, baseline and control scenarios of the pollutant 112 evaluated. After acquiring the required data, the health effects were estimated using the 113 Equation (1):

$$
\Delta Y=Y_{0} * P o p *\left(1-e^{-\beta * \Delta P M}\right)
$$

114 where $\Delta Y$ is the change in health effects incidence (deaths cases); $Y_{0}$ is the baseline 115 incidence (in this case, it is an estimate of the average number of people dying in a given 116 population over a given period); Pop is the exposed population; $\beta$, calculated by Equation

117 (2), is the effect estimated, derived from the relative risk (RR) associated with a change 118 in exposure as expressed in concentration-response function, and obtained from 119 epidemiological studies; and $\triangle P M$ is the $\mathrm{PM}_{2.5}$ concentration change from baseline to 120 control scenario.

$$
\beta=\ln (R R) / \Delta Q
$$

121 where $\Delta Q$ refers to the change in air quality that the epidemiological study used for RR estimation and which is commonly equal to $10 \mu \mathrm{g} \mathrm{m}^{-3}$ for fine particles.

123 As discussed in Section 4, there is no cohort study in Brazil relating to $\mathrm{PM}_{2.5}$ mortality.

124 Therefore, the number of deaths was estimated using concentration-response functions 125 based on most cited/used studies of long-term exposure to $\mathrm{PM}_{2.5}$ conducted on large 126 cohorts in Europe (Cesaroni et al., 2013) and North America (Pope et al., 2002; Pope et 127 al., 2004; Laden et al., 2006; Krewski et al., 2009; Crouse et al., 2012), as summarised in 128 Table 1. The concentration-response functions that were not already included in Ben129 MAP-CE were added based on $\beta$ values and their standard errors. Fann and Risley (2013) 130 reported that there are differences between American Cancer Society study (Pope et al., 131 2002, Pope et al., 2004; Krewski et al., 2009) and the Harvard Six-Cities Study (Laden et 132 al., 2006) such as population size, geographic area covered, education level and $\mathrm{PM}_{2.5}$ 
133 composition. The same may be applied for the studies conducted by Crouse et al. (2012) 134 and Cesaroni et al. (2013). In order to generate a more comprehensive mortality estimate, 135 it was used different exposure-response functions for each cause assessed, but the results 136 must be interpreted by each function individually due to the differences among the 137 methodology used in each cohort study.

138 Table 1. Summary of the main features of selected concentration-response functions.

\begin{tabular}{lllll}
\hline $\begin{array}{l}\text { Health } \\
\text { outcome }\end{array}$ & Reference & $\begin{array}{l}\text { Age } \\
\text { Range }\end{array}$ & $\begin{array}{l}\text { Hazard ratio } \\
\text { (95\% CI) }\end{array}$ & $\boldsymbol{\beta}$ values (STD) \\
\hline \multirow{3}{*}{ All Causes } & Pope et al. (2002) & $30-99$ & $1.06(1.02-1.11)$ & $0.005827(0.002157)$ \\
& Krewski et al. (2009) & $30-99$ & $1.03(1.01-1.05)$ & $0.002956(0.000991)$ \\
& Laden et al. (2006) & $25-74$ & $1.16(1.07-1.26)$ & $0.014842(0.004170)$ \\
\hline \multirow{2}{*}{ Non-Accidental } & Cesaroni et al. (2013) & $>30$ & $1.04(1.03-1.05)$ & $0.003922(0.000491)$ \\
& Crouse et al. (2012) & $>25$ & $1.15(1.13-1.16)$ & $0.013976(0.000668)$ \\
\hline \multirow{3}{*}{ Cardiovascular ar } & Cesaroni et al. (2013) & $>30$ & $1.06(1.04-1.08)$ & $0.005827(0.000963)$ \\
& Crouse et al. (2012) & $>25$ & $1.16(1.13-1.18)$ & $0.014843(0.001104)$ \\
& Laden et al. (2006) & $25-74$ & $1.28(1.13-1.44)$ & $0.024686(0.006184)$ \\
\hline \multirow{3}{*}{ Ischemic Heart } & Pope et al. (2004) & $30-99$ & $1.18(1.14-1.23)$ & $0.016551(0.001938)$ \\
Disease & Krewski et al. (2009) & $30-99$ & $1.15(1.11-1.20)$ & $0.013976(0.001989)$ \\
& Crouse et al. (2012) & $>25$ & $1.31(1.27-1.35)$ & $0.027003(0.001558)$ \\
& Cesaroni et al. (2013) & $>30$ & $1.10(1.06-1.13)$ & $0.009531(0.001631)$ \\
\hline \multirow{2}{*}{ Lung Cancer } & Pope et al. (2002) & $30-99$ & $1.14(1.04-1.23)$ & $0.013103(0.004280)$ \\
& Krewski et al. (2009) & $30-99$ & $1.11(1.04-1.18)$ & $0.010436(0.003222)$ \\
& Cesaroni et al. (2013) & $>30$ & $1.05(1.01-1.10)$ & $0.004879(0.002177)$ \\
\hline
\end{tabular}

\section{2. $\quad \mathbf{P M}_{2.5}$ data}

140 To estimate the health-related benefits, baseline scenarios were defined considering the

141 annual $\mathrm{PM}_{2.5}$ concentrations for all Brazilian cities with representative monitoring data.

142 Figure 1 shows the locations of the monitoring sites of $\mathrm{PM}_{2.5}$ in 2017 (manual and

143 automatic).

144 São Paulo was the first city that started monitoring $\mathrm{PM}_{2.5}$ in Brazil in 2000 with manual 145 measurements (Kumar et al., 2016; Pacheco et al., 2017; Andrade et al., 2017). After 146 2001, a single measurement site was expanded to nine sites in São Paulo by 2017, with 147 automatic stations operating since 2005. Rio de Janeiro city started the $\mathrm{PM}_{2.5}$ monitoring 148 in the middle of 2010 at eight monitoring sites, therefore, a representative annual 149 concentration was available just in 2011. Belo Horizonte, capital of Minas Gerais, started 150 monitoring $\mathrm{PM}_{2.5}$ in 2013 at a single site in the north of the city. Since this monitoring 151 site is located far from the urban center, the values obtained may be underestimated to 152 represent the entire city. Therefore, the avoidable death values may be higher than those 
153 that will be presented. Vitória was the fourth capital of a state in Brazil to monitor $\mathrm{PM}_{2.5}$.

154 The measurements started in 2015 at a single site. All cities and years with $\mathrm{PM}_{2.5}$ 155 concentration values are available in Supplementary Information, SI, Table S1. For the

156 cities with more than one monitoring station, an average was performed to obtain a single

157 value to represent the city.

158 In São Paulo state, the automatic stations use Beta radiation method to measure $\mathrm{PM}_{2.5}$, 159 while manual stations use gravimetric methods (virtual impaction - dichotomous; or 160 impaction and cyclone), performed for 24 hours every six days (CETESB, 2017). In Rio 161 de Janeiro state, the $\mathrm{PM}_{2.5}$ measurements occur with a frequency of six days with a sample 162 of 24 hours. The samples of particulate material are collected in Large Volume Samplers 163 and then analyzed in laboratories by the State Environmental Institute of Rio de Janeiro 164 (INEA, 2016). In the state of Espírito Santo, the Tapered Element Oscillating 165 Microbalance measurement methodology is used for the continuous measurement of the 166 mass concentration of fine particulate material contained in ambient air (IEMA, 2017). 167 In Minas Gerais, an automatic station monitors the $\mathrm{PM}_{2.5}$ concentration in Belo Horizonte 168 using a monitor with Beta radiation method (FEAM, 2016). For criteria of the temporal 169 representativeness of data for the manual stations, half of the daily averages valid for the 170 four-month periods January-April, May-August and September-December were 171 considered, which are the criteria used by São Paulo State Environmental Protection 172 Agency (CETESB).

173 The control scenario was evaluated considering the maximum annual concentration for $174 \mathrm{PM}_{2.5}$ of $10 \mu \mathrm{g} \mathrm{m}^{-3}$. This is the lowest level at which total, cardiopulmonary and lung 175 cancer mortality have been shown to increase with more than $95 \%$ confidence in response 176 to long-term exposure to $\mathrm{PM}_{2.5}$ (WHO, 2006). Therefore, the benefits will only be 177 evaluated if the baseline scenario concentrations are higher than the control scenario. 

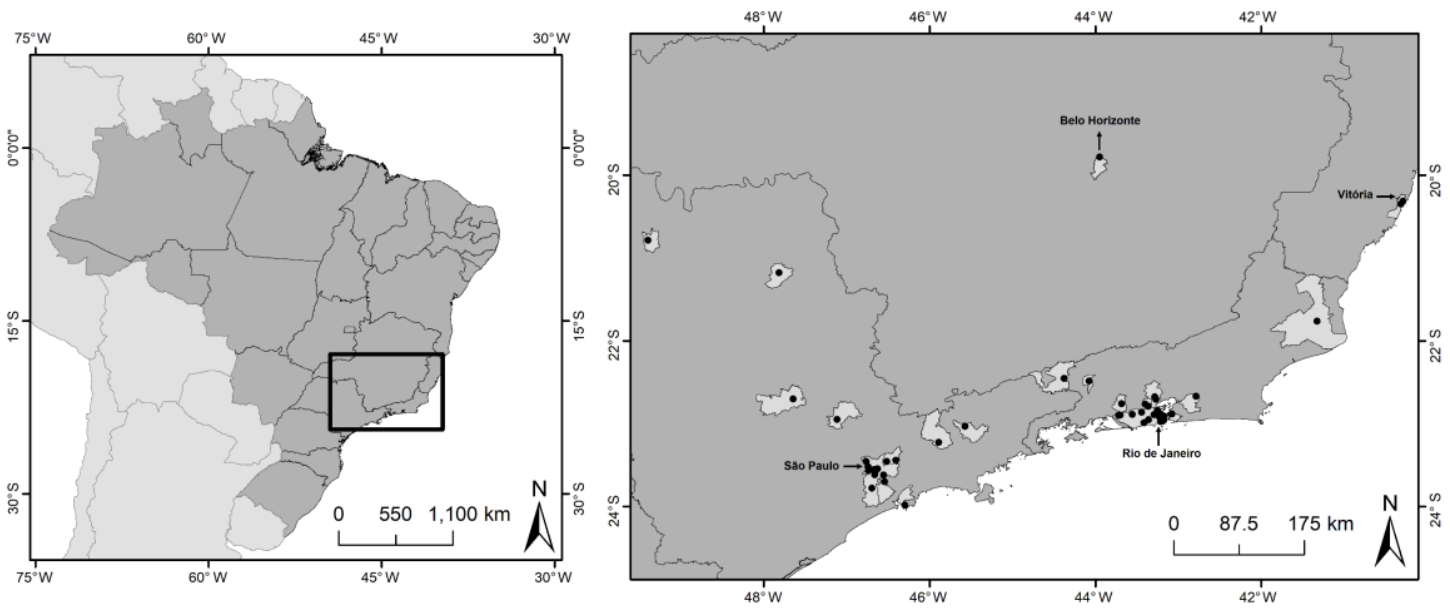

Figure 1 - Locations of the monitoring sites of $\mathrm{PM}_{2.5}$ in Brazil (2017).

\section{$180 \quad 2.3 \quad$ Population and mortality data}

181 Annually population data were obtained from Departamento de Informática do Sistema

182 Único de Saúde (DATASUS) for each city by age group from 2000 to 2015. Population

183 data from 2000 to 2013 are preliminary estimates made in a study sponsored by Rede

184 Interagencial de Informações para a Saúde (Ripsa), while this data from 2013 to 2015 are

185 preliminary estimates prepared by Coordenação-Geral de Informações e Análises

186 Epidemiológicas (CGIAE) of the Secretariat of Health Surveillance (Secretaria de

187 Vigilância em Saúde - SVS), Ministry of Health (Ministério da Saúde - MS). To estimate

188 the health effects for 2016 and 2017, population data of 2015 was used.

189 Annually mortality data by age group due all causes (ICD-10: A00-Y98), all non190 accidental causes (ICD-10: A00-R99), ischemic heart disease (ICD-10: I20-I25), 191 cardiovascular (ICD-10: I20-I28, I30-I52, I60-I79) and lung cancer (ICD-10: C33-C34) 192 was obtained from DATASUS, which regulates mortality data in the Sistema de 193 Informação sobre Mortalidade (SIM). To estimate the health effects for 2017, the incident 194 rate of 2016 was used.

\section{Results}

\subsection{Overview of annual $\mathbf{P M}_{2.5}$ concentrations}

197 About $89 \%$ of the total annual $\mathrm{PM}_{2.5}$ concentration analyzed were higher than WHO 198 guideline $\left(10 \mu \mathrm{g} \mathrm{m}^{-3}\right)$. As for individual cities, Figure 2 shows the annual average 199 concentrations of $\mathrm{PM}_{2.5}$ in São Paulo city over the period of between 2000 and 2017, 
200 showing the annual concentration always above the WHO guideline. There were some

201 periods with a decrease in concentration to $14.6 \mu \mathrm{g} \mathrm{m}^{-3}$ in 2009 , followed by periods with increased concentrations to $20.2 \mu \mathrm{g} \mathrm{m}^{-3}$ in 2011. In 2011, there was a decrease in rainfall, with periods of drought and low humidity, probably as a consequence of the planetary scale phenomenon known as La Niña. The winter in 2011, like the previous year, was among the most unfavorable to the dispersion of the pollutants (CETESB, 2012). Plainly, there is no clear trend in $\mathrm{PM}_{2.5}$ concentrations over the years, but there has been a steady reduction in concentration values over the most recent years from $19.1 \mu^{\mathrm{g} \mathrm{m}^{-3}}$ in 2014 to $16.1 \mathrm{\mu g} \mathrm{m}^{-3}$ in 2017 , mainly because of the reduction in the number of days unfavorable to the dispersion of pollutants during the winter period (CETESB, 2017). Other cities of

210 the São Paulo state, such as São Caetano do Sul and Guarulhos, obtaining annual 211 concentrations higher than São Paulo $\left(18 \mu \mathrm{g} \mathrm{m}^{-3}\right.$ in both cities in 2017). All the 212 concentration values for the 11 cities of São Paulo state are available in SI Table S1 for 213 the years with monitoring data (2000 to 2017).

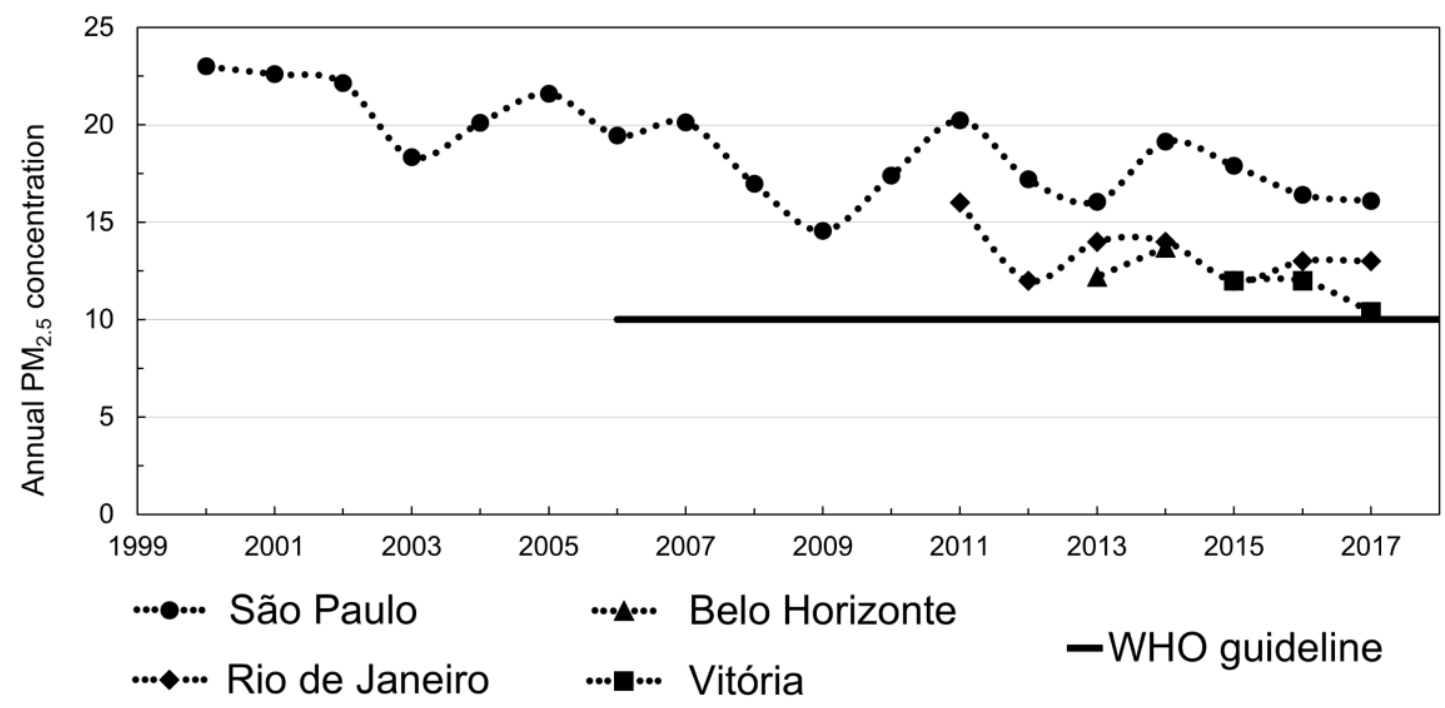

Figure 2 - Annual PM 2.5 concentration for São Paulo, Rio de Janeiro, Belo Horizonte and

217 Figure 2 also shows average annual $\mathrm{PM}_{2.5}$ concentrations for Rio de Janeiro. In the seven 218 evaluated years, $\mathrm{PM}_{2.5}$ levels decreased and increased, with no single tendency, with all 219 concentration values being higher than that recommended by the WHO. For 2016 and 2202017 , the annual concentration was $13 \mu \mathrm{g} \mathrm{m}^{-3}$. According to Godoy et al. (2018), in Rio 221 de Janeiro, the vehicular contribution to $\mathrm{PM}_{2.5}$ ranged from 48 to $70 \%$, with a mean value 222 of $59 \pm 9 \%$, during the period from June 2012 to June 2013. Another study carried out from 
2232003 to 2005 showed that sources related to anthropogenic sources as vehicle traffic and 224 oil combustion, represented about $65 \%$ of the $\mathrm{PM}_{2.5}$ fraction in Rio de Janeiro (Godoy et 225 al., 2009). The other cities of Rio de Janeiro state obtained annual $\mathrm{PM}_{2.5}$ concentration 226 values between 8 and $22 \mu \mathrm{g} \mathrm{m}^{-3}$ (SI Table S1).

227 In 2013, the annual $\mathrm{PM}_{2.5}$ concentration in Belo Horizonte was $12.2 \mu \mathrm{g} \mathrm{m}^{-3}$ as opposed to $22813.7 \mu_{\mathrm{g} \mathrm{m}^{-3}}$ in 2014. These are values below than those reported by Miranda et al. (2012) 229 for June 2007 to August $2008\left(14.7 \mu \mathrm{g} \mathrm{m}^{-3}\right)$. Recent monitoring data was not available.

230 The annual $\mathrm{PM}_{2.5}$ concentration in Vitória over 2015-2016 was $12 \mu \mathrm{g} \mathrm{m}^{-3}$, slightly above 231 the WHO guidelines. In 2017, the annual concentration dropped down a bit more to 10.4 $232 \mu \mathrm{g} \mathrm{m}^{-3}$. Vila Velha is the other city in Espírito Santo state with a monitoring station. The 233 annual levels for these two first years were 11.4 and $11 \mu \mathrm{g} \mathrm{m}^{-3}$, while in 2017 the concentration dropped to $9.7 \mu \mathrm{g} \mathrm{m}^{-3}$, lower than the WHO guidelines.

235 In 2014, 92\% of the world population was living in places where WHO air quality 236 guideline standards were not met (WHO, 2017). Figure 3 shows a comparison of annual $237 \mathrm{PM}_{2.5}$ concentration in 2014 among São Paulo, Rio de Janeiro, Belo Horizonte and other 238 cities around the world. In South America, Bogotá (Colombia) and Santiago (Chile) 239 presented annual concentrations higher than those observed in Brazilian cities, exceeding $24020 \mu \mathrm{g} \mathrm{m}^{-3}$. In the Central Valley of Chile, during most of the year, there is a thermal 241 inversion layer, which favors the accumulation of pollution (Valdés et al., 2012). On the 242 other hand, Montevideo (Uruguay), a coastal city, present a concentration lower than 243 WHO guideline, as Sydney in Australia. In Shanghai and Beijing (China), the average 244 annual concentration of $\mathrm{PM}_{2.5}$ was $52 \mu \mathrm{g} \mathrm{m}^{-3}$ and $85 \mu \mathrm{g} \mathrm{m}^{-3}$, respectively, mainly due to 245 motor vehicles emissions (Chan and Yao, 2008; Liu et al., 2014). Paris (France) and 246 Singapore presented values similar to São Paulo, with an annual $\mathrm{PM}_{2.5}$ concentration of $24718 \mathrm{\mu g} \mathrm{m}^{-3}$ (WHO, 2016b). 


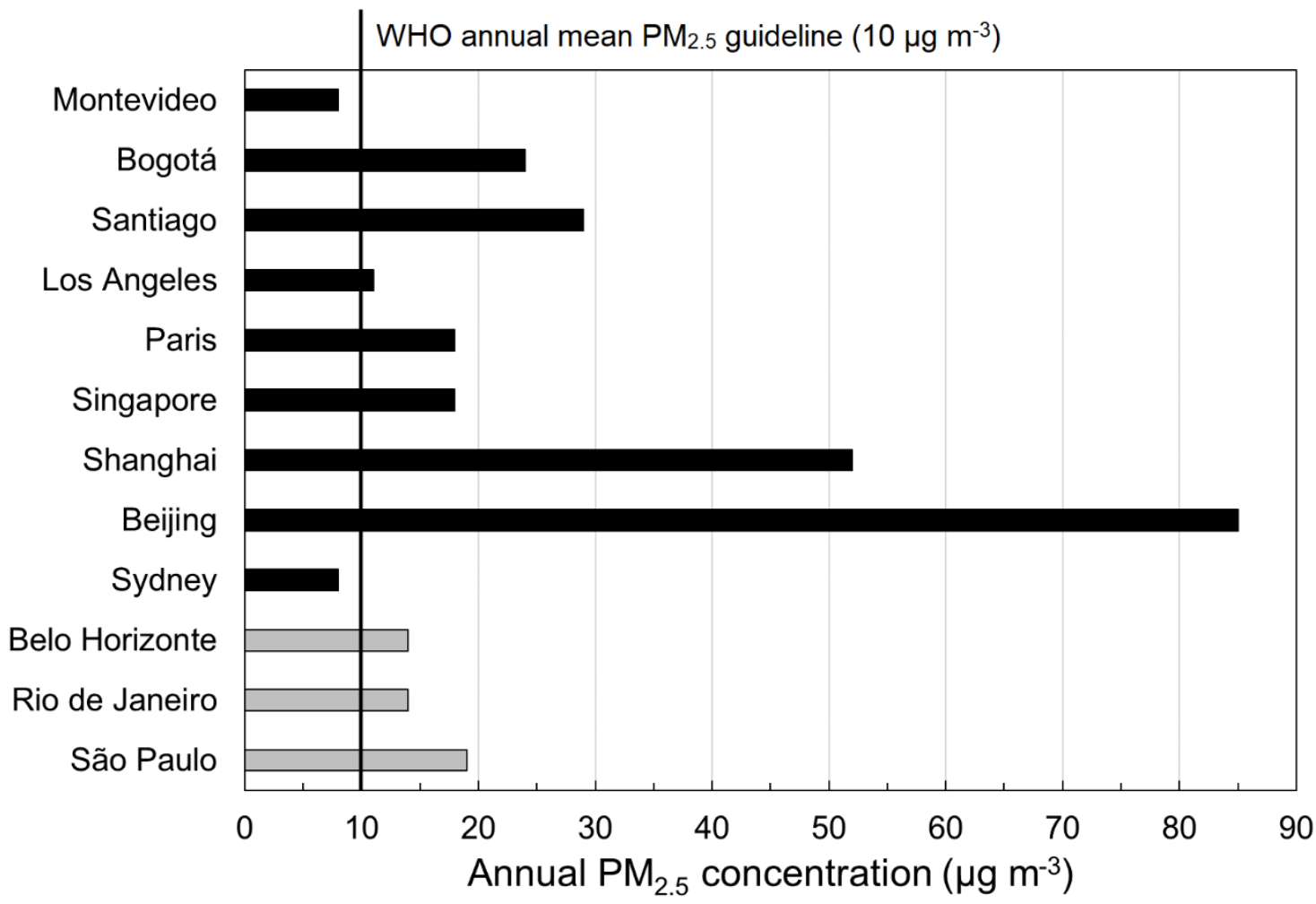

249 Figure 3 - Annual $\mathrm{PM}_{2.5}$ concentration in 2014 from different cities around the world (WHO,

250 2016b). The cities covered in our assessment are presented in grey color.

\section{$251 \quad 3.2$ Population and mortality overview}

252 São Paulo is the city with the largest population in Brazil (7.7 million of inhabitants over

25325 years in 2015). From 2000, it was observed an increase in the first ten years for all age 254 groups. After 2010, just the age group 25 to 29 years old presented a decline, while the 255 other groups still growing up in population. In total numbers, the population increases $25630 \%$ from 2000 to 2015 , reaching 7.7 million of inhabitants in 2015 . When the total 257 number of deaths is observed, the age groups until 49 years presented a decrease of $34.4 \%$ 258 from 2000 to 2016 , while the deaths for the group formed with people with more than 80 259 years went up $90.5 \%$. However, the population of this group more than duplicated in this 260 period and, therefore, the incident rate (deaths/population) presented a decrease of $19 \%$.

261 Figure 4 shows the incident rate for all causes over the years. For the younger groups 262 ( $<44$ years), the incidence rate is lower than 0.005 . 


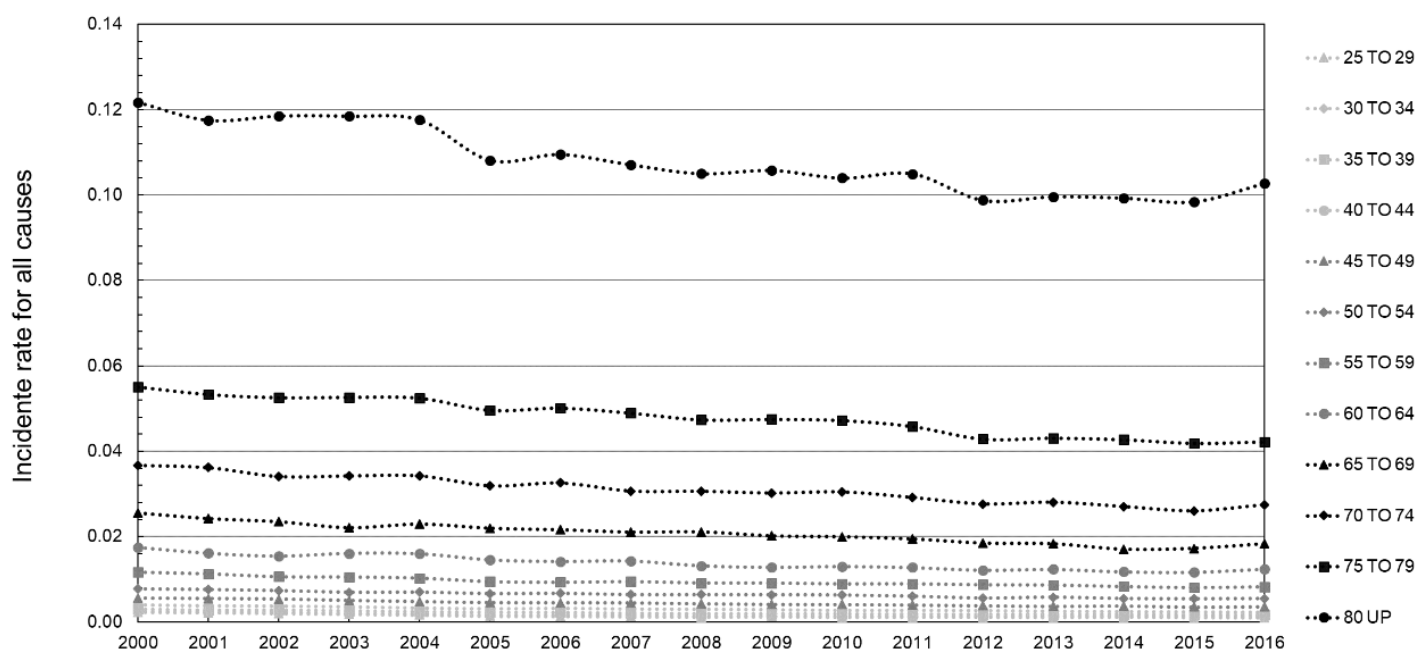

Figure 4 - Incident rate for São Paulo city (over 25 years) by age group over the years.

265 Figure 5 shows the number of deaths for the population (over 25 years) of São Paulo city 266 by all causes, all non-accidental causes, IHD, cardiovascular and lung cancer. In absolute 267 number, there was an increase of deaths for all five causes (22\% for all causes, $29 \%$ for non-accidental, $12 \%$ for cardiovascular, $5 \%$ for IHD and 34\% for lung cancer, between 2000 and 2016). However, when the incident rate is evaluated, it was observed that just for lung cancer this increase remains the same (i.e., 2.9\% of increase from 2000 to 2016). The other causes obtained reductions in incident rate: $6.3 \%$ for all causes; $0.8 \%$ for nonaccidental; $14.2 \%$ for cardiovascular and $19.6 \%$ for IHD, for the same period.

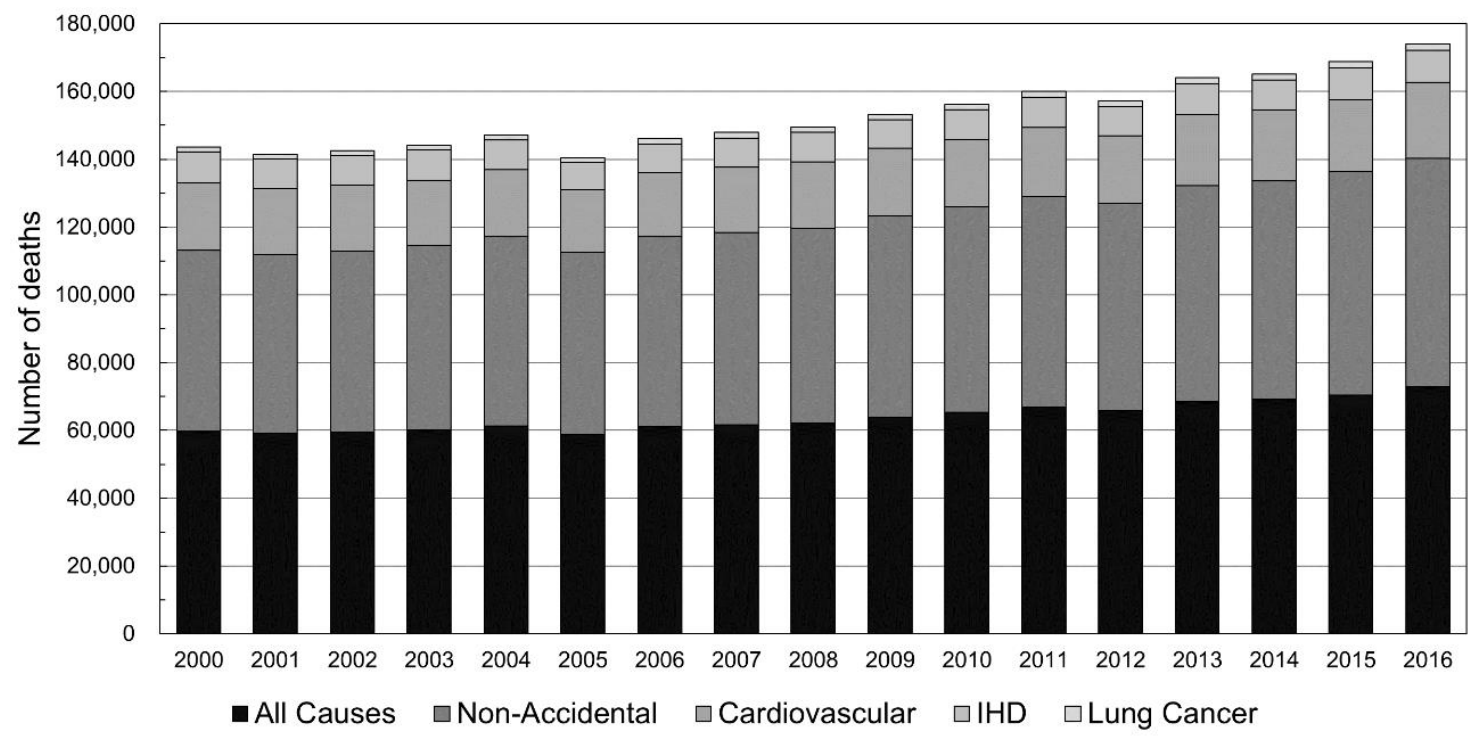

Figure 5 - Total number of deaths for the population (over 25 years) of São Paulo.

275 Rio de Janeiro city presented an increase of $3.9 \%$ in the number of inhabitants (over 25 years) from 2011 to 2015 , reaching approximately 4.2 million. Although some age groups 
277 such as 25 to 29 years and 45 to 49 years showed a decrease of $7.5 \%$ and 5\%, respectively, 278 over the years. Concerning mortality, the age group with more than 80 years old presented 279 the highest number of deaths, for all causes evaluated. The incident rate increases when 280 the populations get older. There is, for the most of age groups, a decline in incident rate 281 for all five causes over the years evaluated. An exception is, for example, an increase of $2828 \%$ in the incidence rate for groups up to 44 years for cardiovascular disease. Other 283 increases also found were for the groups of 25 to 29 and 35 to 39 years for non-accidental 284 causes, $24 \%$ and 4\%, respectively. Compared to São Paulo, Rio de Janeiro had an incident 285 rate higher for all causes and non-accidental causes in all age groups. For cardiovascular 286 diseases, lower values were found. For the other causes, there were higher and lower 287 values depending on the age group.

288 Belo Horizonte presented a population with more than 25 years of approximately 1.7 289 million inhabitants in 2015. The incident rates evaluated were lower than those for São 290 Paulo and Rio de Janeiro for all five causes and age groups.

291 The population over 25 years of Vitória was more than 233 thousand inhabitants in 2015. 292 Compared to Rio de Janeiro, Vitória presented lower values of the incident rate in 2015 293 for all causes and non-accident causes, for all age groups. Some higher values were found 294 for IHD and lung cancer, especially for the smallest age groups, as for example, for the age group 30 to 34 years, which presented values $40 \%$ and $80 \%$ higher than Rio de Janeiro for IHD and lung cancer, respectively. Compared to Belo Horizonte, the values for IHD,

297 which are higher, are highlighted. Compared to São Paulo, lower values of incident rate 298 were found for all causes, non-accidental causes, cardiovascular diseases and IHD, for 299 the majority of age groups. On the other hand, the incident rate for lung cancer was higher 300 for most of the age groups.

301 In São Paulo state, other cities presented incident rate values higher than those found in 302 São Paulo city. For example, in 2015, Guarulhos presented higher values for almost all 303 age group in all the five causes evaluated. Campinas obtained higher values for all causes, 304 non-accidental causes, and lung cancer. Similar situation for Taubaté, which also 305 presented higher values for IHD. In Rio de Janeiro state, compared to the capital, 306 practically all cities presented an incidence rate greater in 2015, with a highlight for 307 Duque de Caxias that presented values superior to the other cities for most causes and age 
groups. In Espírito Santo, Vila Velha presented incident rates greater than Vitória for the most causes and age groups.

3103.3 Avoided premature mortality against WHO guideline for annual mean 311 concentrations of $\mathbf{P M} 2.5$

312 Table 2 summarizes the avoided mortalities for all causes, non-accidental causes,

313 cardiovascular, IHD and lung cancer for the city of São Paulo for some years. A detailed

314 list of annual mortality estimates between 2000 and 2017 can be found in SI Tables S16

315 to S18. As expected, São Paulo presented the highest values of avoidable deaths among

316 all cities studied. When considering the concentration-response function of Pope et al.

317 (2002), the analysis indicated a number of avoidable deaths for all causes ranging from

$3181,657 \pm 619$ (in 2009) to 4,284 1,625 (in 2000). Depending on the selected relative risk,

319 the maximum value can reach $7,097 \pm 2,137$ avoidable deaths. This number represents

$32018 \%$ of the total deaths in 2000 (25 to 74 years old). The results obtained with Krewski

321 et al. (2009) relative risk were the lower among all cause category. Adding the avoidable

322 deaths from 2000 to 2017, between $28,874 \pm 9,769$ and 82,720 $\pm 24,549$ people would not

323 have prematurely died due to $\mathrm{PM}_{2.5}$ in São Paulo, depending on the cohort study.

324 Table 2 - Estimate of avoidable deaths for the city of São Paulo, with the standard 325 deviation in parentheses.

\begin{tabular}{llllll}
\hline $\begin{array}{l}\text { Health } \\
\text { outcome }\end{array}$ & $\begin{array}{l}\text { Exposure-response } \\
\text { functions }\end{array}$ & $\mathbf{2 0 0 0}$ & $\mathbf{2 0 0 9}$ & $\mathbf{2 0 1 5}$ & $\mathbf{2 0 1 7}$ \\
\hline \multirow{4}{*}{ All Causes } & Pope et al. (2002) & $4,284(1,625)$ & $1,657(619)$ & $3,120(1,172)$ & $2,509(939)$ \\
& Krewski et al. (2009) & $2,215(752)$ & $846(285)$ & $1,601(541)$ & $1,284(433)$ \\
& Laden et al. (2006) & $7,097(2,137)$ & $2,423(698)$ & $4,176(1,223)$ & $3,379(980)$ \\
\hline Non- & Cesaroni et al. (2013) & $2,676(342)$ & $1,049(132)$ & $1,995(253)$ & $1,615(204)$ \\
Accidental & Crouse et al. (2012) & $9,056(472)$ & $3,693(182)$ & $6,893(347)$ & $5,634(281)$ \\
\hline \multirow{3}{*}{ Cardiovascular } & Cesaroni et al. (2013) & $1,481(253)$ & $524(88)$ & $950(160)$ & $775(130)$ \\
& Crouse et al. (2012) & $3,578(291)$ & $1,314(101)$ & $2,352(185)$ & $1,932(150)$ \\
& Laden et al. (2006) & $3,294(929)$ & $1,102(288)$ & $1,930(519)$ & $1,609(426)$ \\
\hline \multirow{5}{*}{ Ischemic } & Pope et al. (2004) & $1,783(230)$ & $617(75)$ & $1,118(139)$ & $904(111)$ \\
Heart Disease & Krewski et al. (2009) & $1,531(236)$ & $524(77)$ & $954(142)$ & $769(113)$ \\
& Crouse et al. (2012) & $2,730(186)$ & $986(6)$ & $1,764(112)$ & $1,438(90)$ \\
& Cesaroni et al. (2013) & $1,074(194)$ & $361(63)$ & $662(117)$ & $531(93)$ \\
\hline \multirow{4}{*}{ Lung Cancer } & Pope et al. (2002) & $224(78)$ & $98(33)$ & $189(64)$ & $144(48)$ \\
& Krewski et al. (2009) & $182(59)$ & $78(25)$ & $152(48)$ & $116(37)$ \\
& Cesaroni et al. (2013) & $88(40)$ & $37(17)$ & $73(33)$ & $55(25)$ \\
\hline
\end{tabular}


326 The avoidable deaths for non-accidental cause with the relative risk of Crouse et al. (2012) 327 in 2017 were $67 \%$ to $339 \%$ higher than those found for all-cause, while the relative risk 328 of Cesaroni et al. (2013) presented lower values, except when compared with Krewski et 329 al. (2009) results. For cardiovascular and IHD, the results obtained with Crouse et al. 330 (2012) were very high compared to others (reaching $173 \%$ higher), while the relative risk 331 pointed out by Cesaroni et al. (2013) results in the lower values.

332 Considering the relative risk of Pope et al. (2002) for lung cancer, the avoidable deaths

333 were more representative in relation to the total number of deaths by lung cancer for the 334 first eight years (2000 to 2007). Until 2007, the average of representativeness was $13.3 \%$, 335 while from 2008 to 2017 it was $8.9 \%$. Considering the entire period, this average reached $33610.9 \%$.

337 The year 2017 presented the highest number of monitoring sites for $\mathrm{PM}_{2.5}$ in São Paulo 338 state (20 stations in 11 cities). Table 3 shows the values of avoidable deaths in four of 339 these cities for this year. The complete series of avoidable deaths are presented in SI 340 Tables S9 to S15. Guarulhos city, which is at the border of São Paulo city, showed the 341 highest values of avoidable deaths among the other cities of São Paulo state $(524 \pm 153$, 342 considering the concentration-response function of Laden et al. (2006) for all causes). 343 Campinas, further north of São Paulo city, also presented high values (more than double 344 of the average in these cities). It is worth pointing out that these two cities presented 345 annual $\mathrm{PM}_{2.5}$ concentration higher than São Paulo (Table S1), what contributed to the 346 higher number of avoidable deaths estimated. São Bernardo do Campo and Santos also 347 presented significant values of avoidable deaths. 
348 Table 3 - Estimate of avoidable deaths for four cities of São Paulo state in 2017, with the 349 standard deviation in parentheses.

\begin{tabular}{llllll}
\hline $\begin{array}{l}\text { Health } \\
\text { outcome }\end{array}$ & $\begin{array}{l}\text { Exposure-response } \\
\text { functions }\end{array}$ & Campinas & Guarulhos & $\begin{array}{l}\text { São Bernardo } \\
\text { do Campo }\end{array}$ & Santos \\
\hline \multirow{3}{*}{ All Causes } & Pope et al. (2002) & $266(100)$ & $320(18)$ & $148(55)$ & $129(48)$ \\
& Krewski et al. (2009) & $136(46)$ & $164(55)$ & $76(26)$ & $66(22)$ \\
& Laden et al. (2006) & $345(101)$ & $524(153)$ & $223(65)$ & $139(40)$ \\
\hline \multirow{2}{*}{ Non-Accidental } & Cesaroni et al. (2013) & $168(21)$ & $202(26)$ & $94(12)$ & $84(11)$ \\
& Crouse et al. (2012) & $583(29)$ & $700(35)$ & $327(16)$ & $291(14)$ \\
\hline \multirow{3}{*}{ Cardiovascular } & Cesaroni et al. (2013) & $76(13)$ & $105(18)$ & $48(8)$ & $39(7)$ \\
& Crouse et al. (2012) & $188(15)$ & $260(20)$ & $119(9)$ & $97(7)$ \\
& Laden et al. (2006) & $150(40)$ & $274(74)$ & $110(29)$ & $64(17)$ \\
\hline \multirow{5}{*}{ Ischemic Heart } & Krewski et al. (2009) & $83(12)$ & $107(16)$ & $42(6)$ & $48(6)$ \\
Disease & Pope et al. (2004) & $154(10)$ & $198(13)$ & $78(5)$ & $41(6)$ \\
& Crouse et al. (2012) & $76(5)$ \\
\hline \multirow{3}{*}{ Lung Cancer } & Cesaroni et al. (2013) & $58(10)$ & $74(13)$ & $29(5)$ & $28(5)$ \\
& Pope et al. (2002) & $14(5)$ & $17(6)$ & $10(3)$ & $7(2)$ \\
& Krewski et al. (2009) & $11(4)$ & $14(4)$ & $8(3)$ & $6(2)$ \\
& Cesaroni et al. (2013) & $5(2)$ & $6(3)$ & $4(2)$ & $3(1)$ \\
\hline
\end{tabular}

350 Table 4 presents the avoidable deaths for the city of Rio de Janeiro for some years. The 351 complete series of avoidable deaths are presented in SI Table S6. The values followed the

352 increase or reduction of the $\mathrm{PM}_{2.5}$ concentration over the years (Figure 2). Considering 353 Pope et al. (2002) relative risks, the all-cause avoidable deaths represent $3.5 \%$ of all 354 deaths in 2011 and lung cancer $7.7 \%$ of deaths by this cause. When the results with 355 Krewski et al. (2009) relative risks is observed, it is noticed that IHD represents $45.5 \%$ 356 of all causes avoidable deaths. The results of 2016 and 2017 were equal due to the same 357 incident rate used and because the annual $\mathrm{PM}_{2.5}$ concentration was equal in this two years. 358 The other cities of Rio de Janeiro state with representative $\mathrm{PM}_{2.5}$ monitoring presented a 359 number of avoidable deaths of about ten times lower. All the values are in presented in $360 \quad$ SI Tables S3 to S8. 
361 Table 4 - Estimate of avoidable deaths for the city of Rio de Janeiro, with the standard 362 deviation in parentheses.

\begin{tabular}{llllll}
\hline $\begin{array}{l}\text { Health } \\
\text { outcome }\end{array}$ & $\begin{array}{l}\text { Exposure-response } \\
\text { functions }\end{array}$ & $\mathbf{2 0 1 1}$ & $\mathbf{2 0 1 3}$ & $\mathbf{2 0 1 5}$ & $\mathbf{2 0 1 7}$ \\
\hline \multirow{3}{*}{ All Causes } & Pope et al. (2002) & $1,725(646)$ & $1,144(427)$ & $595(221)$ & $889(331)$ \\
& Krewski et al. (2009) & $883(298)$ & $584(196)$ & $302(102)$ & $453(152)$ \\
& Laden et al. (2006) & $2,339(678)$ & $1,517(435)$ & $780(222)$ & $1,162(332)$ \\
\hline Non- & Cesaroni et al. (2013) & $1,095(138)$ & $726(91)$ & $376(47)$ & $563(71)$ \\
Accidental & Crouse et al. (2012) & $3,819(190)$ & $2,557(126)$ & $1,339(65)$ & $1,995(97)$ \\
\hline \multirow{3}{*}{ Cardiovascular ar } & Cesaroni et al. (2013) & $438(73)$ & $296(49)$ & $156(26)$ & $233(39)$ \\
& Crouse et al. (2012) & $1,090(84)$ & $742(57)$ & $395(30)$ & $589(45)$ \\
& Laden et al. (2006) & $925(245)$ & $614(160)$ & $333(85)$ & $494(127)$ \\
\hline \multirow{3}{*}{ Ischemic Heart } & Pope et al. (2004) & $473(58)$ & $315(38)$ & $164(19)$ & $243(29)$ \\
Disease & Krewski et al. (2009) & $402(59)$ & $267(39)$ & $138(20)$ & $206(30)$ \\
& Crouse et al. (2012) & $749(47)$ & $504(31)$ & $265(16)$ & $392(23)$ \\
& Cesaroni et al. (2013) & $278(49)$ & $184(32)$ & $95(16)$ & $142(25)$ \\
\hline \multirow{2}{*}{ Lung Cancer } & Pope et al. (2002) & $93(31)$ & $65(21)$ & $33(11)$ & $50(16)$ \\
& Krewski et al. (2009) & $75(24)$ & $52(16)$ & $27(8)$ & $40(12)$ \\
& Cesaroni et al. (2013) & $36(16)$ & $24(11)$ & $13(6)$ & $19(8)$ \\
\hline
\end{tabular}

363 Belo Horizonte presented all causes avoidable deaths between $87 \pm 29$ and $246 \pm 70$ in 2013

364 and between $149 \pm 50$ and $410 \pm 117$ in 2014, depending on the cohort study, an increase of

$36568 \%$ on average. Considering the relative risks of Cesaroni et al. (2013), the avoidable

366 deaths for cardiovascular, IHD and lung cancer in 2014 represented 37\%, 15\% and 3\%

367 of the non-accidental deaths.

368 Vitória presented lower values of avoidable deaths. With an improvement of $2 \mu \mathrm{g} \mathrm{m}^{-3}$ on 369 the $\mathrm{PM}_{2.5}$ annual average in 2015 and 2016, the values for all five causes investigated 370 were similar in both years. In 2017 , due to the lower value of annual $\mathrm{PM}_{2.5}$ concentration

$371\left(10.4 \mu \mathrm{g} \mathrm{m}^{-3}\right)$, the benefits observed were lower than 10 avoidable deaths. Figure 6 shows

372 the avoidable deaths per 100 thousand inhabitants for São Paulo, Rio de Janeiro, Belo

373 Horizonte and Vitória, over the years, for all causes and lung cancer, according to the

374 relative risk of Pope et al. (2002). São Paulo obtained the higher values for all causes,

375 followed by Rio de Janeiro and Belo Horizonte. Vitória presented low values for the three 376 years with monitoring data, with the values for all causes reaching levels of those for lung 377 cancer for the other cities in 2017 , due to lower annual $\mathrm{PM}_{2.5}$ concentration and lower 378 population. 


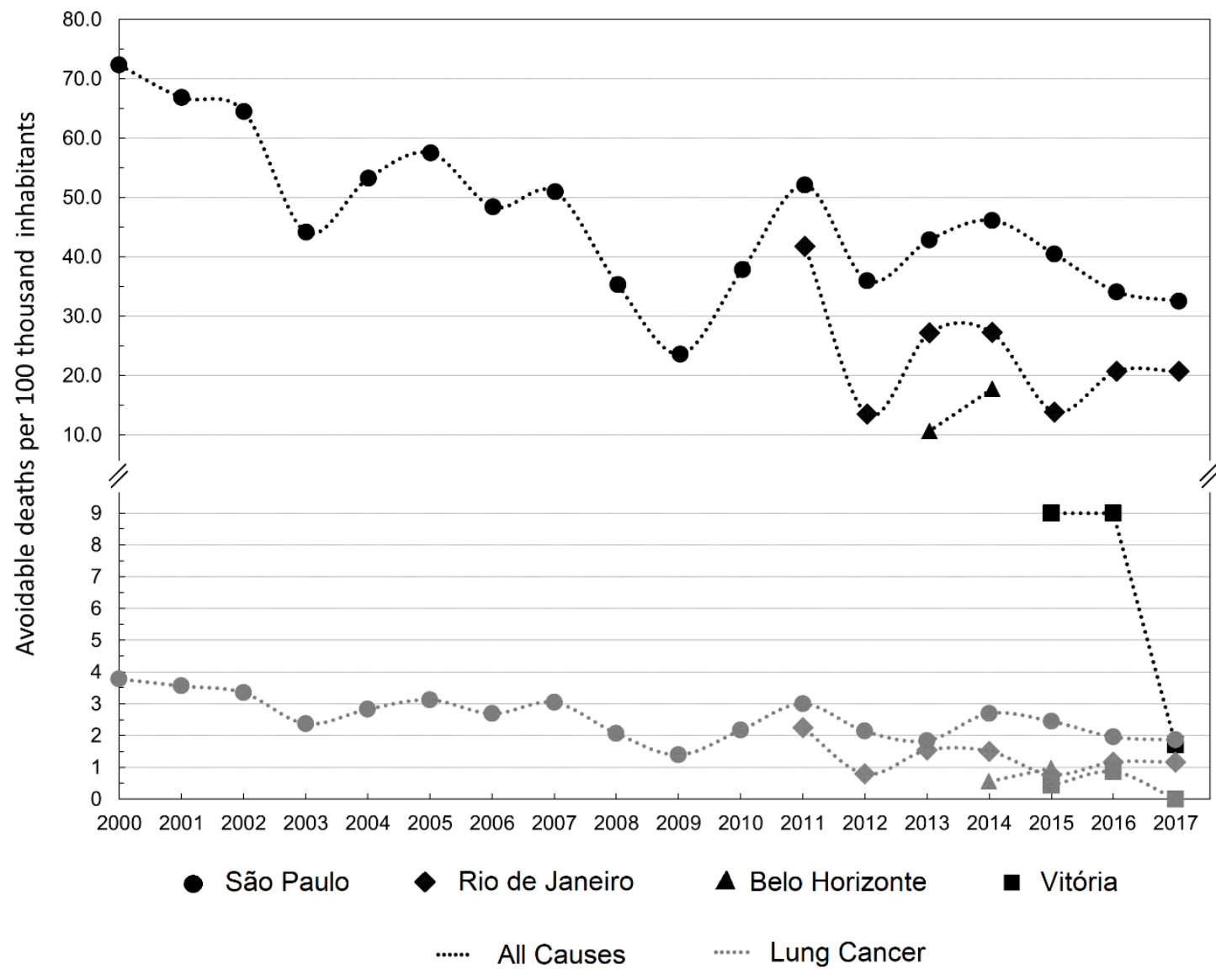
Horizonte and Vitória, over the years, for all causes and lung cancer.

382 Figure 7 shows the avoidable deaths from 2014 to 2017 by non-accidental causes 383 according to Cesaroni et al. (2013). It is noticed that the large urban centers obtained the 384 higher values, mainly due the population size. In some cities, the estimative was not 385 possible because the annual $\mathrm{PM}_{2.5}$ concentration was not available, or it was not 386 representative. For the cities with zero avoidable deaths, the $\mathrm{PM}_{2.5}$ concentration was 387 below the WHO recommendation. 

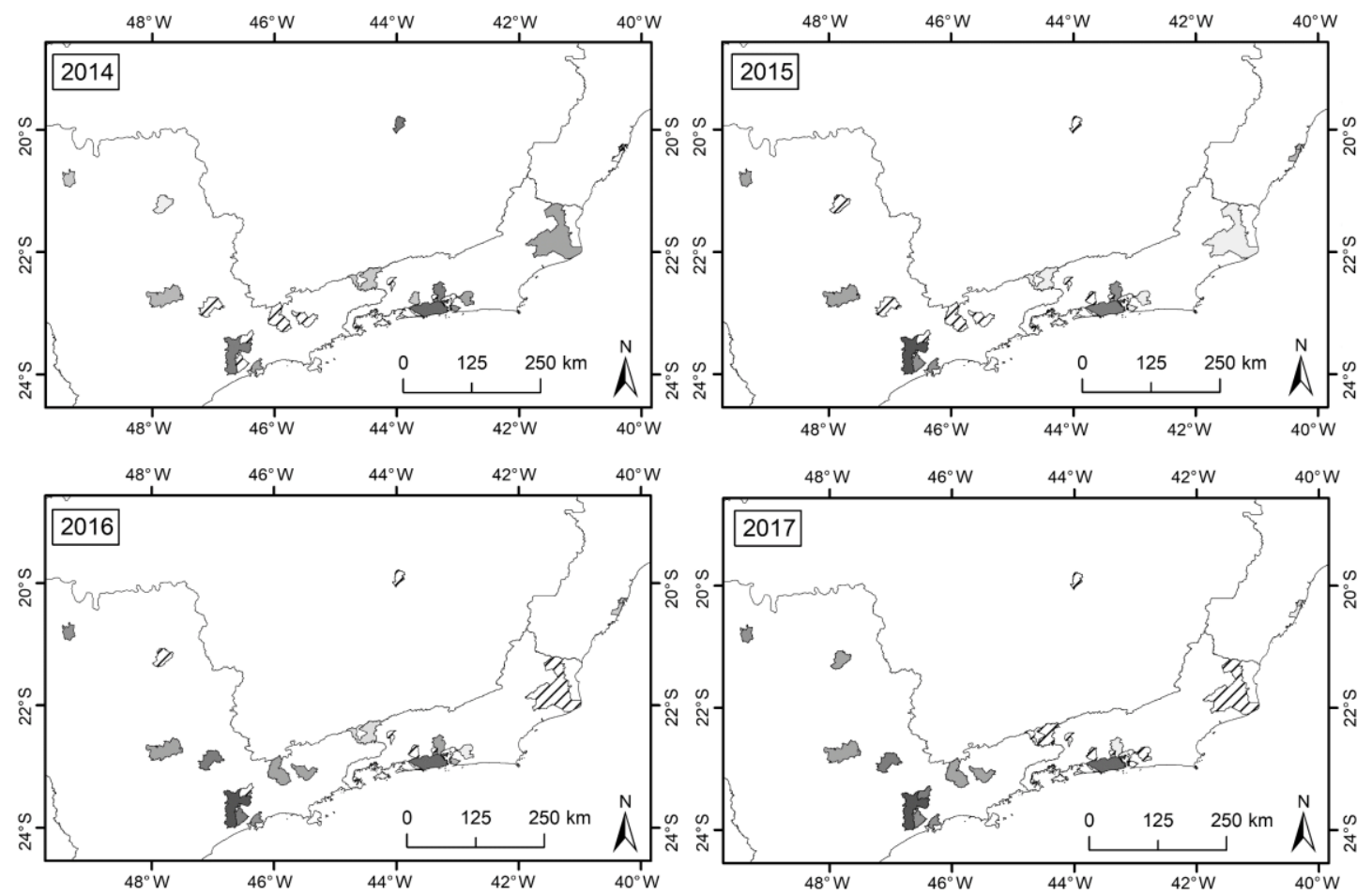

$\square 0.0 \quad \square .0-10.0 \square 20.0-50.0 \square 100.1-500.0 \square>1000$
$\square 0.0-5.00 \square 10.0-20.0 \square 50.0-100.0 \square 500.1-1000$ W/I// not available

389 Figure 7 - Avoidable deaths for non-accidental causes using Cesaroni et al. (2013) relative risk.

\section{Discussion}

391 The accuracy of the estimated air pollution impact on health in a specific city, region or

392 country depends on air pollution concentrations and exposure, population groups

393 exposed, background incidence of mortality or morbidity, and concentration-response

394 functions. The choice of which health outcomes to include in the assessment may be

395 determined by the strength of available studies, the accessibility of health information,

396 and the importance of the impact from a health and economic perspective (WHO, 2006).

397 However, the decision on which epidemiological studies to use and how to apply them to 398 evaluate the health impact assessment is left to the analyst.

399 Epidemiological studies allow estimating the effects of a pollutant on human health. The 400 relationship between changes in short-term air pollution levels and changes in various 401 indicators of population health or the health of individuals is studied in time series, panels, 402 and case timeline studies (Eftim and Dominici, 2005; WHO, 2006). These studies provide 403 the basis to examine the short-term benefits of an improvement on air quality (Lin et al., 404 2016a; 2016b; Chen et al., 2017; Gopalakrishnan et al., 2018). The estimation of chronic 405 health effects associated with air pollution is carried out through cohort studies, which 
examine the risk of a health outcome (e.g. death) in relation to long-term environmental exposure to pollution, generally comparing people living in different geographical locations (Eftim and Dominici, 2005; WHO, 2006).

Cohort studies generally provide higher estimates of pollution effects than time-series studies, indicating that long-term exposures have a greater effect than short-term 411 exposures (Eftim and Dominici, 2005). The disadvantages in carrying out this type of 412 study are logistical difficulties, high implementation costs, monitoring of study 413 populations over long periods of time with great potential for losses, and a large number 414 of individuals generally required to carry out the study. In addition, since exposure is 415 generally considered as a city-wide average, different sites need to be assessed to ensure adequate variability of exposure (WHO, 2006).

417 Most of the cohort studies in the air pollution literature focused primarily on mortality 418 and provided the most comprehensive estimates of the number of deaths attributable to 419 exposure to pollution and the extent of the average reduction in life expectancy. 420 Therefore, they were considered adequate for health impact assessment (Künzli et al., 421 2001; Cohen et al., 2004, Chen et al., 2008).

422 There are some time series studies in Brazil, mainly in São Paulo, relating air pollution 423 and mortality (Saldiva et al., 1994; Saldiva et al., 1995; Gouveia and Fletcher, 2000; 424 Conceição et al., 2001; Gouveia et al., 2003; Freitas et al., 2004; Martins et al., 2004; 425 Daumas et al., 2004; Bravo et al., 2016; Gouveia and Junger, 2018), but none of them 426 evaluated the relationship between fine particulate matter and mortality. Therefore, we 427 have estimated the number of avoidable deaths using cohort studies from the USA, 428 Canada and Italy.

429 The choice of the cohort study that serves as the basis for estimate the health benefits may 430 generate considerable differences. As reported by Boldo et al. (2014), the disparities 431 among the cohort studies could be due to chemical composition of $\mathrm{PM}_{2.5}$ and its 432 heterogeneous mix of particle sizes, thus encompassing the environmental characteristics 433 of each area of study (geographic location, emission sources and pollutants mixtures), the 434 variability among different populations, social-economic conditions and the exposure 435 assessment methodology. Although they are not studies that represent the local fine 436 particulate matter and the Brazilian population, the cohort studies used in this work were 
437 also applied for other countries than those from which they were proposed (Ballester et 438 al., 2008; He et al., 2010; Boldo et al., 2011; Chae and Park, 2011; Nawahda, 2013; Pascal 439 et al., 2013; Boldo et al., 2014; Abe and Miraglia, 2016). Voorhees et al. (2014) reported 440 that it is a common practice to apply concentration-response functions that are not specific 441 to a particular city or region, but which are recognized as being of high quality and 442 produced from well-conducted epidemiological studies. In the extended follow-up of the 443 Harvard Six Cities study (Laden et al., 2006), the historical annual mean $\mathrm{PM}_{2.5}$ 444 concentration was $16.4 \mu \mathrm{g} \mathrm{m}^{-3}$ (range, 11.0-29.6 $\mu_{\mathrm{g} \mathrm{m}^{-3}}$ ); for the ACS study (Pope et al., 445 2002; Pope et al., 2004) was $20 \mu \mathrm{g} \mathrm{m}^{-3}\left(9.0-33.5 \mu \mathrm{g} \mathrm{m}^{-3}\right)$; for the Rome study (Cesaroni 446 et al., 2013) was $43.6 \mu \mathrm{g} \mathrm{m}^{-3}$ (13.0-75.2 $\left.\mu \mathrm{g} \mathrm{m}^{-3}\right)$; and for the Canadian study was $8.7 \mu \mathrm{g}$ $447 \mathrm{~m}^{-3}\left(1.9-19.2 \mu \mathrm{g} \mathrm{m}^{-3}\right)$. The annual concentrations observed in the present study attend the 448 range of these cohort studies. Furthermore, the 10th revision of the International 449 Statistical Classification of Diseases and Related Health Problems were used according 450 to the health outcome described by the cohort studies, as the population age interval. 451 Therefore, the results presented provide a good picture for environmental authorities 452 develop air quality policies.

453 The comparison between the results of avoidable deaths obtained in this work with other 454 similar ones in the world should be done carefully, considering the differences related to 455 the concentration-response function used, age groups and the $\mathrm{PM}_{2.5}$ concentration 456 difference between the baseline and control scenarios. Boldo et al., (2014) showed that 457 an improvement of $4.7 \mu \mathrm{g} \mathrm{m}^{-3}$ in Madrid (Spain) between the years 2007 and 2014 458 resulted in a total of 30, 8 and 4 annual avoidable deaths per 100,000 inhabitants due to 459 all causes, ischemic heart disease, and lung cancer, respectively. In New York City, 65 460 premature deaths due all causes per 100,000 inhabitants were estimated, based on the 461 difference relative to nonanthropogenic, policy-relevant background concentrations, 462 which represented approximately $5 \%$ of average $\mathrm{PM}_{2.5}$ concentrations in New York City 463 (Kheirbek et al., 2013). The improvements of air quality in Japan by reducing the 464 emissions of $\mathrm{PM}_{2.5}$ from 2006 to 2009 could save 28,400 lives (> 65 years) based on a 465 reduction target of $10 \mu \mathrm{g} \mathrm{m}^{-3}$ annual mean concentration (Nawahda, 2013). In Shanghai, 466 the estimated impact on all causes mortality of a year exposure to an annual mean $\mathrm{PM}_{2.5}$ 467 concentration was 1,100 deaths from October 2010 to September 2011 and 180 deaths 468 from October 2011 to September 2012 (Voorhees et al., 2014). 
469 In Brazil, the Resolution CONAMA 03/1990 defines the primary and secondary air 470 quality standards. It is nationally legislated the total suspended particles, smoke, inhalable 471 particles $\left(\mathrm{PM}_{10}\right)$, sulfur dioxide $\left(\mathrm{SO}_{2}\right)$, carbon monoxide $(\mathrm{CO})$, ozone $\left(\mathrm{O}_{3}\right)$ and nitrogen 472 dioxide $\left(\mathrm{NO}_{2}\right)$. As may be noted, they are standards dating back to 1990 and today, 473 because of the whole body of scientific studies related to air pollution and health, they 474 can be considered outdated standards. Moreover, fine particles are not legislated. 475 Therefore, the states of São Paulo and Espírito Santo created they own air quality 476 legislation, with more restrictive standards over time. They also included standards for 477 fine particles, considering the WHO guideline of $\mathrm{PM}_{2.5}$ as the final standard.

478 In São Paulo, although there was an increase in the number of vehicles and in the consumption of fuels, pollutant concentrations have decreased in the last ten years, except 480 for ozone and $\mathrm{PM}_{2.5}$ (Carvalho et al., 2015; Andrade et al., 2017). Vehicular traffic, 481 especially diesel-powered, is a major source of black carbon in urban areas (Sanchéz482 Ccoyllo et al., 2009; Wang et al., 2011; Alves et al., 2015). These emissions may come 483 from the exhaust, physical wear of tires, brakes, and roads (Pant and Harrison, 2013; 484 Andrade et al., 2017). In São Paulo, Rio de Janeiro and Belo Horizonte, black carbon 485 explained approximately $30 \%$ of the $\mathrm{PM}_{2.5}$ mass (Andrade et al., 2012; Andrade et al., 486 2014). Black carbon is an important indicator to evaluate the adverse health effects for 487 being one of the main components of the primary combustion particles (Janssen et al., 488 2011; WHO, 2012; Li et al., 2016). Some cohort studies have identified a positive 489 relationship between mortality (all causes, natural causes, cardiopulmonary, respiratory, 490 lung cancer) and long-term exposure to black carbon (Filleul et al. 2005; Lipfert et al. 491 2006; Beelen et al. 2008; Smith et al. 2009). This shows the importance of adoption of 492 control programs which aim to reduce $\mathrm{PM}_{2.5}$ emission and concentration in the 493 atmosphere in urban centers.

494 In this work, we investigated 24 Brazilian municipalities that monitor $\mathrm{PM}_{2.5}$. These cities 495 represent $16.7 \%$ of the total inhabitants above 25 years old (in 2015) in the country. In 496 relation to the total number of mortalities across Brazil, these municipalities account for $49717.5 \%$ of all-causes, $18.0 \%$ of non-accidental, $18.9 \%$ of cardiovascular, $20.0 \%$ of IHD, 498 and $19.6 \%$ of lung cancer deaths, according DATASUS/SIM system. WHO (2018) 499 estimated 613 deaths per 100,000 inhabitants in Brazil in 2016 attributable to ambient air 500 pollution. Our work showed that 16 Brazilian cities faced annual $\mathrm{PM}_{2.5}$ concentration 
501 above WHO guidelines in 2016 and there were about 28 avoidable deaths per 100,000

502 inhabitants in these cities.

503 Although the main centers normally obtain the highest PM concentrations (Boldo et al., 504 2014; Chen et al., 2017), in this study it was verified that cities around capitals presented 505 higher annual $\mathrm{PM}_{2.5}$ concentration, as for example, São Caetano do Sul and Guarulhos in 506 São Paulo and Belfort Roxo and Duque de Caxias in Rio de Janeiro. This shows the 507 importance of a monitoring that covers several areas, and, in terms of emission control 508 strategies, the entire metropolitan region should be considered.

509 The increase in the elderly population observed has also consequences and implications 510 for society and public health. The vulnerable population have higher incidence rate and 511 therefore are the ones benefitting the most from an improved air quality. It is also 512 important to have an air quality database available and up-to-date so that the population 513 can have access to current and past levels of pollutants, both for the conduct of research 514 and to serve as a public policy instrument.

\section{Conclusions}

516 Adopting the WHO's $\mathrm{PM}_{2.5}$ annual air quality guidelines, between 2,378 \pm 801 and $5176,282 \pm 1,818$ deaths due to all causes could be avoidable in 2017 in just 15 evaluated cities 518 in Brazil. These numbers show the importance of adoption of a $\mathrm{PM}_{2.5}$ guideline in Brazil 519 and improving the monitoring of air quality, expanding throughout the national territory. 520 As $\mathrm{PM}_{2.5}$ is also produced via secondary formation in the atmosphere (Seinfeld and 521 Pandis, 2006), reducing the concentration of other pollutants may result in a decrease of 522 the $\mathrm{PM}_{2.5}$ formation. Policies and investments supporting cleaner transport, power 523 generation, industry emissions control and better municipal waste management would 524 reduce key sources of fine particles and reduce the exposure.

525 The accuracy of results depends on air quality data, exposed population, concentration-

526 response functions and mortality incidence rates. The population and mortality data were 527 obtained from a national database. Therefore, the results are expected to be affected by 528 the air quality data and concentration-response functions. It was used a single annual $529 \mathrm{PM}_{2.5}$ concentration to represent each city. But it is known that there are large variations 530 in concentration across different geographic and meteorological areas, even within a city. 531 For some cities, there was more than one monitoring station, which makes the value 
532 obtained more representative, including the local traffic emissions and long-range 533 transport contributions. However, in other, as Belo Horizonte, just one monitoring site 534 was available, sometimes far for the urban center. Therefore, the concentration value 535 obtained may not represent the real mean concentration for the city but is still an indicator

536 of local pollution and may represent a minimum value that would be found in the urban 537 center for that city. As an alternative for monitoring data is the use of photochemical 538 models, as CMAQ and WRF-Chem, for example. However, an emission inventory with 539 high spatial resolution is required, as a well-described meteorological field. In addition, 540 the modeled results must be validated with monitoring concentrations and the effect of 541 spatial resolution must be evaluated (Punger and West, 2013; Jiang and Yoo, 2018).

542 The actual impact of air pollution on health presented here shows the importance of 543 adopting more restrictive air quality standards. Such information is essential to 544 implementing, monitoring and evaluating policies that help to tackle air pollution while 545 also protecting health. Therefore, a review of the nation Brazilian air quality standards is 546 necessary, as the inclusion of pollutants not yet legislated, as $\mathrm{PM}_{2.5}$. The importance of 547 using local cohort studies to estimate health benefits is also recorded. Unfortunately, in 548 Brazil, long-term cohort studies for $\mathrm{PM}_{2.5}$ are non-existent.

\section{Acknowledgments}

550 This research was partially funded by Coordenação de Aperfeiçoamento de Pessoal de 551 Nível Superior (CAPES), Brazil.

\section{References}

553 Alves, C.A., Lopes, D.J., Calvo, A.I., Evtyugina, M., Rocha, S., Nunes, T., 2015. 554 Emissions from Light-Duty Diesel and Gasoline In-Use Vehicles Measured on Chassis 555 Dynamometer Test Cycles. Aerosol Air Qual. Res., 15, 99-116. 556 doi:10.4209/aaqr.2014.01.0006

557 Andrade, M.F., Miranda, R.M., Fornaro, A., Kerr, A., Oyama, B., Andre, P.A., Saldiva, 558 P.,2012. Vehicle emissions and PM2.5 mass concentrations in six Brazilian cities. Air 559 Qual. Atmos. Health, 5, 79-88. doi:10.1007/s11869-010-0104-5

560 Andrade, M., Oyama, B., Fornaro, A., Miranda, R., Saldiva, P., 2014. Application of PMF 561 for Evaluation of the Fine Particles Contribution from Vehicular Emission in Six 562 Brazilian Cities. In: Steyn D., Builtjes P., Timmermans R. (eds) Air Pollution Modeling 563 and its Application XXII. NATO Science for Peace and Security Series C: Environmental 564 Security. Springer, Dordrecht. doi:10.1007/978-94-007-5577-2_28 
565 Andrade, M.F., Kumar, P., Freitas, E.D., Ynoue, R.Y., Martins, J., Martins, L.D., 566 Nogueira, T., Perez-Martinez, P., Miranda, R.M., Albuquerque, T., Gonçalves, F.L.T., 567 Oyama, B., Zhang, Y., 2017. Air quality in the megacity of São Paulo: Evolution over the

568 last 30 years and future perspectives. Atmos. Environ., 159, 66-82. 569 doi:10.1016/j.atmosenv.2017.03.051

570 Ballester, F., Medina, S., Boldo, E., Goodman, P., Neuberger, M., Iniguez, C., Kunzli, 571 N., 2008. Reducing ambient levels of fine particulates could substantially improve health: 572 a mortality impact assessment for 26 European cities. J. Epidemiol. Community Health, 573 62, 98-105. doi:10.1136/jech.2007.059857

574 Beelen, R., Hoek, G., van den Brandt, P., Goldbohm, A., Fischer, P., Schouten, L.J., 575 Jerrett, M., Hughes, E., Armstrong, B., Brunekreef, B., 2008. Long-term effects of traffic576 related air pollution on mortality in a Dutch cohort (NLCS-AIR study). Environ. Health 577 Perspect., 116, 196-202. doi:10.1289/ehp.10767

578 Bentayeb, M., Wagner, V., Stempfelet, M., Zins, M., Goldberg, M., Pascal, M., Larrieu, 579 S., Beaudeau, P., Cassadou, S., Eilstein, D., Filleul, L., Le Tertre, A., Medina, S., Pascal, 580 S., Prouvost, H., Quénel, P., Zeghnoun, A., Lefranc, A., 2015. Association between long581 term exposure to air pollution and mortality in France: A 25-year follow-up study. 582 Environ. Int., 85, 5-14. doi:10.1016/j.envint.2015.08.006

583 Boldo, E., Linares, C., Lumbreras, J., Borge, R., Narros, A., García-Pérez, J., Fernández584 Navarro, P., Pérez-Goméz, B., Aragonés, N., Ramis, R., Pollán, M., Moreno, T., 585 Karanasiou, A., López-Abente, G., 2011. Health impact assessment of a reduction in 586 ambient $\mathrm{PM}_{2.5}$ levels in Spain. Environ. Int., 37, 342-348. 587 doi:10.1016/j.envint.2010.10.004

588 Boldo, E., Linares, C., Aragonés, N., Lumbreras, J., Borge, R., De La Paz, D., Pérez589 Goméz, B., Fernández-Navarro, P., García-Pérez, J., Pollán, M., Ramis, R., Moreno, T., 590 Karanasiou, A., López-Abente, G., 2014. Air quality Modeling and mortality impact of 591 fine particles reduction policies in Spain. Environ. Res., 128, 15-26. 592 doi:10.1016/j.envres.2013.10.009

593 Brazil, 2014. $1^{\circ}$ Diagnóstico de rede de monitoramento da qualidade do ar no Brasil. São 594 Paulo: Instituto de Energia e Meio Ambiente.

595 Bravo, M.A., Son, J., Freitas, C.U., Gouveia, N., Bell, M.L., 2016. Air pollution and 596 mortality in São Paulo, Brazil: Effects of multiple pollutants and analysis of susceptible 597 populations. J. Expo. Sci. Env. Epid., 26, 150-161. doi:10.1038/jes.2014.90

598 Carvalho, V.S.B., Freitas, E.D., Martins, L.D., Martins, J.A., Mazzoli, C.R., Andrade, 599 M.F., 2015. Air quality status and trends over the Metropolitan Area of São Paulo, Brazil 600 as a result of emission control policies. Environ. Sci. Policy, 47, 68-79. 601 doi:10.1016/j.envsci.2014.11.001

602 Cesaroni, G., Badaloni, C., Gariazzo, C., Stafoggia, M., Sozzi, R., Davoli, M., Forastiere, 603 F., 2013. Long-term exposure to urban air pollution and mortality in a cohort of more 604 than a million adults in Rome. Environ. Health Persp., 121, 324-331. 605 doi:10.1289/ehp.1205862

606 CETESB, 2012. Qualidade do ar no estado de São Paulo, 2011. Companhia Ambiental 607 do Estado de São Paulo (São Paulo State Environmental Protection Agency). Available 608 in: http://ar.cetesb.sp.gov.br/publicacoes-relatorios/. Accessed in March/2018. 
609 CETESB, 2017. Qualidade do ar no estado de São Paulo, 2016. Companhia Ambiental 610 do Estado de São Paulo (São Paulo State Environmental Protection Agency). Available 611 in: http://ar.cetesb.sp.gov.br/publicacoes-relatorios/. Accessed in March/2018.

612 Chae, Y., Park, J., 2011. Quantifying costs and benefits of integrated environmental 613 strategies of air quality management and greenhouse gas reduction in the Seoul 614 Metropolitan Area. Energy Policy, 39, 5296-5308. doi:10.1016/j.enpol.2011.05.034

615 Chan, C.K., Yao, X., 2008. Air pollution in mega cities in China. Atmos. Environ., 42, 1616 42. doi:10.1016/j.atmosenv.2007.09.003

617 Chen, H., Goldberg, M.S., Villeneuve, P.J., 2008. A systematic review of relation 618 between long-term exposure to ambient air pollution and chronic disease. Rev. Environ. 619 Health, 23, 243-296. doi:10.1515/REVEH.2008.23.4.243

620 Chen, L., Shi, M., Gao, S., Li, S., Mao, J., Zhang, H., Sun, Y., Bai, Z., Wang, Z., 2017. 621 Assessment of population exposure to PM2.5 for mortality in China and its public health 622 benefit based on BenMAP. Environ. Pollut., 221, 311-317. 623 doi:10.1016/j.envpol.2016.11.080

624 Cohen, A.J., Anderson, H.R., Ostro, B., Pandey, K.D., Krzyzanowski, M., Künzli, N., 625 Gutschmidt, K., Pope III, C.A., Romieu, I., Samet, J.M., Smith, K.R., 2004. Urban Air 626 Pollution. In: Ezzati, M., Lopez, A. D., Rodgers, A., Murray, C. J. L. Urban air pollution 627 In: Ezzati, M., Lopez, A. D., Rodgers, A., Murray, C. J. L. editors. Comparative 628 quantification of health risks: global and regional burden of disease attributable to 629 selected major risk factors. Genebra: World Health Organization, 1353-1433.

630 Cohen, A.J., Brauer, M., Burnett, R., Anderson, H., Frostad, J., Estep, K., Balakrishnan, 631 K., Brunekreef, B., Dandona, L., Dandona, R., Feigin, V., Freedman, G., Hubbell, B., 632 Jobling, A., Kan, H., Knibbs, L., Liu, Y., Martin, R., Morawska, L., Pope III, C.A., Shin, 633 H., Straif, K., Shaddick, G., Thomas, M., Van Dingenen, R., Van Donkelaar, A., Vos, T., 634 Murray, C.J.L., Forouzanfar, M.H., 2017. Estimates and 25-year trends of the global 635 burden of disease attributable to ambient air pollution: an analysis of data from the Global 636 Burden of Diseases Study 2015. Lancet, 389, 1907-1918. doi:10.1016/S0140637 6736(17)30505-6

638 Conselho Nacional do Meio Ambiente. Resolução CONAMA $n^{\circ}$ 03, de 22 de agosto de 639 1990. Dispõe sobre padrões de qualidade do ar, previstos no PRONAR. Brasília, 22 ago. 640 1990. Available in http://www.mma.gov.br/port/conama/res/res90/res0390.html. Access 641 in February/2018.

642 Conceição, G.M.S., Miraglia, S.G.E.K., Kishi, H.S., Saldiva, P.H.N., Singer, J.M., 2001. 643 Air Pollution and Child Mortality: A Time-Series Study in São Paulo, Brazil. Environ. 644 Health Persp., 109 (Suppl 3), 347-350. doi:10.2307/3434781

645 Crouse, D.L., Peters, P.A., Van Donkelaar, A., Goldberg, M.S., Villeneuve, P.J., Brion, 646 O., Khan, S., Atari, D.O., Jerrett, M., Pope III, C.A., Brauer, M., Brook, J.R., Martin, 647 R.V., Stieb, D., Burnett, R.T., 2012. Risk of nonaccidental and cardiovascular mortality 648 in relation to long-term exposure to low concentrations of fine particulate matter: A 649 Canadian national-level cohort study. Environ. Health Persp., 120, 708-714. doi: $650 \quad 10.1289 /$ ehp.1104049

651 Curtis, L., Rea, W., Smith-Willis, P., Fenyves, E., Pan, Y., 2006. Adverse health effects 652 of outdoor air pollutants. Environ. Int., 32, 815-830. doi:10.1016/j.envint.2006.03.012 
653 Daumas, R.P., Mendonça, G.A.S., León, A.P., 2005. Poluição do ar e mortalidade em 654 idosos no Município do Rio de Janeiro: análise de série temporal. Cad. Saúde Pública, 655 20, 311-319. doi: 10.1590/S0102-311X2004000100049

656 Eftim, S., Dominici, F., 2005. Multisite time-series studies versus cohort studies: 657 methods, findings, and policy implications. J. Toxicol. Env. Heal. A, 68, 1191-1205. 658 doi:10.1080/15287390590936076

659 Fann, N., Risley, D., 2013. The public health context for $\mathrm{PM}_{2.5}$ and ozone air quality 660 trends. Air Qual. Atmos. Health, 6, 1-11. doi:10.1007/s11869-010-0125-0

661 FEAM, 2016. Monitoramento da Qualidade do ar Região Metropolitana de Belo 662 Horizonte, 2016. Fundação Estadual do Meio Ambiente (Minas Gerais State 663 Environmental Protection Agency). Available in: http://www.feam.br/noticias/1/1331664 relatorios-e-publicacoes. Accessed in March/2018.

665 Filleul, L., Rondeau, V., Vandentorren, S., Le Moual, N., Cantagrel, A., Amnesi666 Maesano, I. Charpin, D., Declercq, C., Neukirch, F., Paris, C., Vervloet, D., Brochard, P., 667 Tessier, J.F., Kauffmann, F., Baldi, I., 2005. Twenty five year mortality and air pollution: 668 results from the French PAARC survey. Occup. Environ. Med., 62, 453-460. 669 doi:10.1136/oem.2004.014746

670 Freitas, C., Bremner, S.A., Gouveia, N., Pereira, L.A.A., Saldiva, P.H.N., 2004. 671 Internações e óbitos e sua relação com a poluição atmosférica em São Paulo, 1993 a 1997. 672 Rev. Saúde Publ., 38, 751-757. doi:10.1590/S0034-89102004000600001

673 Godoy, M.L.D.P., Godoy, J.M., Roldão, L.A., Soluri, D.S., Donagemma, R.A., 2009. 674 Coarse and fine aerosol source apportionment in Rio de Janeiro, Brazil. Atmos. Environ., 675 43, 2366-2374. doi:10.1016/j.atmosenv.2008.12.046

676 Godoy, M.L.D.P., Almeida, A.C., Tonietto, G.B., Godoy, J.M., 2018. Fine and Coarse 677 Aerosol at Rio de Janeiro prior to the Olympic Games: Chemical Composition and Source 678 Apportionment. J. Braz. Chem. Soc., 29, 499-508. doi:10.21577/0103-5053.20170162

679 Gopalakrishnan, V., Hirabayashi, S., Ziv, G., Bakshi, B.R., 2018. Air quality and human 680 health impacts of grasslands and shrublands in the United States. Atmos. Environ., 182, 681 193-199. doi:10.1016/j.atmosenv.2018.03.039

682 Gouveia, N., Fletcher, T., 2000. Time series analysis of air pollution and mortality: effects 683 by cause, age and socioeconomic status. J. Epidemiol. Commun. H., 54, 750-755. 684 doi:10.1136/jech.54.10.750

685 Gouveia, N., Mendonça, G.A.S., Leon, A.P., Correia, J.E.M., Junger, W.L., Freitas, C.U., 686 Daumas, R.P., Martins, L.C., Giussepe, L., Conceição, G.M.S., Manerich, A., Cunha687 Cruz, J., 2003. Poluição do ar e efeitos na saúde nas populações de duas grandes 688 metrópoles brasileiras. Epidemiol. Serv. Saúde, 12, 29-40. doi:10.5123/S167968949742003000100004

690 Gouveia, N., Junger, W.L., 2018. Effects of air pollution on infant and children 691 respiratory mortality in four large Latin-American cities. Environ. Pollut., 232, 385-391. 692 doi:10.1016/j.envpol.2017.08.125

693 He, K., Lei, Y., Pan, X., Zhang, Y., Zhang, Q., Chen, D., 2010. Co-benefits from energy 694 policies in China. Energy, 35, 4265-4272. doi:10.1016/j.energy.2008.07.021

695 IEMA, 2017. Relatório da Qualidade do ar Grande Vitória 2014. Instituto Estadual de 696 Meio Ambiente e Recursos Hídricos. (Espírito Santo State Environmental Protection 
697 Agency). Available in: https://iema.es.gov.br/qualidadedoar/relatorios. Accessed in $698 \mathrm{March} / 2018$.

699 INEA, 2016. Relatório da Qualidade do ar do estado do Rio de Janeiro 2015. Instituto

700 Estadual do Ambiente (Rio de Janeiro State Environmental Protection Agency).

701 Available in:

702 http://www.inea.rj.gov.br/Portal/MegaDropDown/Monitoramento/Monitoramentodoar-

703 EmiQualidade/Qualidoar/RelatorioAnualAr/index.htm\&lang=. Accessed in March/2018.

704 Janssen, N.A.H., Hoek, G., Simic-Lawson, M., Fischer, P., van Bree, L., ten Brink, H.,

705 Keuken, M., Atkinson, R.W., Anderson, H.R., Brunekreef, B., Cassee, F.R., 2011. Black

706 Carbon as an Additional Indicator of the Adverse Health Effects of Airborne Particles

707 Compared with $\mathrm{PM}_{10}$ and $\mathrm{PM}_{2.5}$. Environ. Health Persp., 119, 1691-1699. doi:

708 10.1289/ehp.1003369

709 Jiang, X., Yoo, E., 2018. The importance of spatial resolutions of Community Multiscale

710 Air Quality (CMAQ) models on health impact assessment. Sci. Total Environ., 627, 1528-

711 1543. doi:10.1016/j.scitotenv.2018.01.228

712 Katanoda, K., Sobue, T., Satoh, H., Tajima, K., Suzuki, T., Nakatsuka, H., Takezaki, T., 713 Nakayama, T., Nitta, H., Tanabe, K., Tominaga, S., 2011. An Association Between Long-

714 Term Exposure to Ambient Air Pollution and Mortality from Lung Cancer and 715 Respiratory Diseases in Japan. J. Epidemiol., 21, 132-143. doi:10.2188/jea.JE20100098

716 Kheirbek, I., Wheeler, K., Walters, S., Kass, D., Matte, T., 2013. PM 2.5 and ozone health 717 impacts and disparities in New York City: sensitivity to spatial and temporal resolution.

718 Air Qual. Atmos. Health, 6, 473-486. doi:10.1007/s11869-012-0185-4

719 Krewski, D., Jerrett, M., Burnett, R.T., Ma, R., Hughes, E., Shi, Y., Turner, M.C., Pope

720 III, C.A., Thurston, G., Calle, E.E., Thun, M.J., 2009. Extended follow-up and spatial 721 analysis of the American Cancer Society study linking particulate air pollution and 722 mortality. HEI Research Report 140. Boston: Health Effects Institute.

723 Kumar, P., Andrade, M.F., Ynoue, R.Y., Fornaro, A., Freitas, E.D., Martins, J.L.D., 724 Albuquerque, T., Zhang, Y., Morawska, L., 2016. New Directions: From biofuels to wood 725 stoves: the modern and ancient air quality challenges in the megacity of São Paulo. Atmos. 726 Environ. 140, 364-369. doi:10.1016/j.atmosenv.2016.05.059

727 Künzli, N., Medina, S., Kaiser, R., Quénel, P., Horak Jr., F., Studnicka, M., 2001. 728 Assessment of Deaths Attributable to Air Pollution: Should We Use Risk Estimates based 729 on Time Series or on Cohort Studies? Am. J. Epidemiol., 153, 1050-1055. 730 doi:10.1093/aje/153.11.1050

731 Laden, F., Schwartz, J., Speizer, F.E., Dockery, D.W., 2006. Reduction in fine particulate 732 air pollution and mortality: extended follow-up of the Harvard six cities study. Am. J. 733 Resp. Crit. Care, 173, 667-672. doi:10.1164/rccm.200503-443OC

734 Lepeule, J., Laden, F., Dockery, D., Schwartz, J., 2012. Chronic Exposure to Fine 735 Particles and Mortality: An Extended Follow-up of the Harvard Six Cities Study from 7361974 to 2009. Environ. Health Persp., 120, 965-970, 2012. doi:10.1289/ehp.1104660

737 Li, Y., Henze, D.K., Jack, D., Henderson, B.H., Kinney, P.L., 2016. Assessing public 738 health burden associated with exposure to ambient black carbon in the United States. Sci. 739 Total Environ., 539, 515-525. doi:10.1016/j.scitotenv.2015.08.129

740 Lin, H., Liu, T., Xiao, J., Zeng, W., Li, X., Guo, L., Xu, Y., Zhang, Y., Vaughn, M.G., 741 Nelson, E.J., Qian, Z., Ma, W., 2016a. Quantifying short-term and long-term health 
742 benefits of attaining ambient fine particulate pollution standards in Guangzhou, China.

743 Atmos. Environ., 137, 38-44. doi:10.1016/j.atmosenv.2016.04.037

744 Lin, H., Liu, T., Xiao, J., Zeng, W., Li, X., Guo, L., Zhang, Y., Xu, Y., Tao, J., Xian, H., 745 Syberg, K.M., Qian, Z., Ma, W., 2016b. Mortality burden of ambient fine particulate air 746 pollution in six Chinese cities: Results from the Pearl River Delta study. Environ. Int., 747 96, 91-97. doi:10.1016/j.envint.2016.09.007

748 Lipfert, F.W., Baty, J.D., Miller, J.P., Wyzga, R.E., 2006. PM 2.5 constituents and related 749 air quality variables as predictors of survival in a cohort of U.S. military veterans. Inhal. 750 Toxicol., 18, 645-657. doi:10.1080/08958370600742946

751 Liu, Z.R., Hu, B., Liu, Q., Sun, Y., Wang, Y.S., 2014. Source apportionment of urban 752 fine particle number concentration during summertime in Beijing. Atmos. Environ., 96, 359-369. doi:10.1016/j.atmosenv.2014.06.055

Martins, M.C., Fatigati, F.L., Véspoli, T.C., Martins, L.C., Pereira, L.A., Martins, M.A., Saldiva, P.H., Braga, A.L., 2004. Influence of socioeconomic conditions on air pollution adverse health effects in elderly people: an analysis of six regions in São Paulo, Brazil. $J$. Epidemiol. Community Health, 58, 41-46. doi: 10.1136/jech.58.1.41

758 Martins, L.D., Wikuats, C.F.H., Capucim, M.N., Almeida, D.S., Costa, S.C., 759 Albuquerque, T., Carvalho, V.S.B., Freitas, E.D., Andrade, M.F., Martins, J.A., 2017.

760 Extreme value analysis of air pollution data and their comparison between two large urban 761 regions of South America. Weather and Climate Extremes, 18, 44-54. 762 doi:10.1016/j.wace.2017.10.004

763 McMichael, A.J., 2000. The urban environment and health in a world of increasing 764 globalization: issues for developing countries. Bull World Health Organ., 78, 1117-1126.

765 Miranda, R.M., Andrade, M.F., Fornaro, A., Astolfo, R., Andre, P.A., Saldiva, P., 2012. 766 Urban air pollution: a representative survey of $\mathrm{PM}_{2.5}$ mass concentrations in six Brazilian 767 cities. Air Qual. Atmos. Health, 5, 63-77. doi:10.1007/s11869-010-0124-1

768 Nawahda, A., 2013. Reductions of $\mathrm{PM}_{2.5}$ Air Concentrations and Possible Effects on 769 Premature Mortality in Japan. Water Air Soil Pollut., 224:1508. doi:10.1007/s11270-013$770 \quad 508-2$.

771 Pacheco, M.T., Parmigiani, M.M.M., Andrade, M.F., Morawska, L., Kumar, P., 2017. A 772 review of emissions and concentrations of particulate matter in the three metropolitan 773 areas of Brazil. Journal of Transport and Health, 4, 53-72. doi:10.1016/j.jth.2017.01.008

774 Pant, P., Harrison, R.M., 2013. Estimation of the contribution of road traffic emissions to 775 particulate matter concentrations from field measurements: A review. Atmos. Environ., 776 77, 78-97. doi: 10.1016/j.atmosenv.2013.04.028

777 Pascal, M., Corso, M., Chanel, O., Declercq, C., Badaloni, C., Cesaroni, G., Henschel, S., 778 Meister, K., Haluza, D., Martin-Olmedo, P., Medina, S., 2013. Assessing the public 779 health impacts of urban air pollution in 25 European cities: Results of the Aphekom 780 project. Sci. Total Environ., 449, 390-400. doi:10.1016/j.scitotenv.2013.01.077.

781 Pope III, C.A., Burnett, R.T., Thun, M.J., Calle, E.E., Krewski, D., Ito, K., Thurston, 782 G.D., 2002. Lung cancer, cardiopulmonary mortality, and long-term exposure to fine 783 particulate air pollution. J. Am. Med. Assoc., 287, 1132-1141. 784 doi:10.1001/jama.287.9.1132

785 Pope III, C.A., Burnett, R.T., Thurston, G.D., Thun, M.J., Calle, E.E., Krewski, D., 786 Godleski, J.J., 2004. Cardiovascular mortality and long-term exposure to particulate air 
787 pollution: epidemiological evidence of general pathophysiological pathways of disease.

788 Circulation, v. 109, p. 71-77. doi:10.1161/01.CIR.0000108927.80044.7F

789 Punger, E.M., West, J., 2013. The effect of grid resolution on estimates of the burden of 790 ozone and fine particulate matter on premature mortality in the USA. Air Qual. Atmos. 791 Health, 6, 563-573. doi:10.1007/s11869-013-0197-8

792 Sack, J.D., Lloyd, J.M., Zhu, Y., Anderton, J., Jang, C. J., Hubbell, B., Fann, N., 2018. 793 The Environmental Benefits Mapping and Analysis Program - Community Edition 794 (BenMAP-CE): A tool to estimate the health and economic benefits of reducing air 795 pollution. Environ. Modell. Softw., 104, 118-129. doi:10.1016/j.envsoft.2018.02.009

796 Saldiva, P.H.N., Lichtenfels, A.J.F.C., Paiva, P.S.O., Barone, I.A., Martins, M.A., 797 Massad, E., Pereira, J.C.R., Xavier, V.P., Singer, J.M., Bohm, G.M., 1994. Association 798 between Air Pollution and Mortality Due to Respiratory Diseases in Children in São 799 Paulo, Brazil: A Preliminary Report. Environ. Res., 65, 218-225. 800 doi:10.1006/enrs.1994.1033

801 Saldiva, P.H.N., Pope III, C.A., Schwartz, J., Dockery, D.W., Lichtenfels, A.J., Salge, 802 J.M., Barone, I., Bohm, G.M., 1995. Air Pollution and Mortality in Elderly People: A 803 Time-Series Study in Sao Paulo, Brazil. Arch. Environ. Health, 50, 159-163. 804 doi:10.1080/00039896.1995.9940893

805 Sanchez-Ccoyllo, O.R., Ynoue, R.Y., Martins, L.D., Astolfo, R., Miranda, R.M., Freitas, 806 E.D., Borges, A.S., Fornaro, A., Freitas, H., Moreira, A., Andrade, M.F., 2009. Vehicular 807 particulate matter emissions in roads tunnels in São Paulo, Brazil. Environ. Monit. 808 Assess., 149, 241-249, 2009. doi:10.1007/s10661-008-0198-5

809 Seinfeld, J. H., Pandis, N.S., 2006. Atmospheric Chemistry and Physics: From air 810 pollution to climate change. 2. ed. USA: Wiley - Interscience Publication.

811 Smith, K.R., Jerrett, M., Anderson, H.R., Burnett, R.T., Stone, V., Derwent, R., Atkinson, 812 R.W., Cohen, A., Shonkoff, S.B., Krewski, D., Pope III, C.A., Thun, M.J., Thurston, G., 813 2009. Public health benefits of strategies to reduce greenhouse-gas emissions: health 814 implications of short-lived greenhouse pollutants. Lancet, 374, 2091-2103. 815 doi:10.1016/S0140-6736(09)61716-5

816 The World Bank, 2018. Urban population (\% of total). Available online: 817 https://data.worldbank.org/indicator/SP.URB.TOTL.IN.ZS. Accessed in March/2018.

818 Thurston, G.D., Burnett, R.T., Turner, M.C., Shi, Y., Krewski, D., Lall, R., Ito, K., Jerrett, 819 M., Gapstur, S.M., Diver, W.R., Pope III, C.A., 2016. Ischemic heart disease mortality 820 and long-term exposure to source-related components of U.S. fine particle air pollution. 821 Environ. Health Persp., 124, 785-794. doi:10.1289/ehp.1509777.

822 United Nations, Department of Economic and Social Affairs, Population Division, 2015. 823 World Urbanization Prospects: The 2014 Revision, (ST/ESA/SER.A/366).

824 Valdés, A., Zanobetti, A., Halonen, J.I., Cifuentes, L., Morata, D., Schwartz, J., 2012. 825 Elemental concentrations of ambient particles and cause specific mortality in Santiago, 826 Chile: a time series study. Environ. Health, 11, 82. doi: 10.1186/1476-069X-11-82

827 Voorhees, A.S., Wang, J., Wang, C., Zhao, B., Wang, S., Kan, H., 2014. Public health 828 benefits of reducing air pollution in Shanghai: A proof-of-concept methodology with 829 application to BenMAP. Sci. Total Environ., 485-486, 396-405. 830 doi:10.1016/j.scitotenv.2014.03.113 
831 Wang, X., Westerdahl, D., Wu, Y., Pan, X., Zhang, K.M., 2011. On-road emission factor 832 distributions of individual diesel vehicles in and around Beijing, China. Atmos. Environ., 833 45, 503-513.

834 World Health Organization, 2006. Air quality guidelines: global update 2005.

835 World Health Organization, 2012. Health Effects of Black Carbon.

836 World Health Organization, 2016a. World health statistics 2016: monitoring health for 837 the SDGs, sustainable development goals.

838 World Health Organization, 2016b. Exposure City level 2016. Available in: 839 http://apps.who.int/gho/data/view.main.AMBIENTCITY2016?lang=en. Accessed in $840 \mathrm{March} / 2018$.

841 World Health Organization, 2017. World health statistics 2017: monitoring health for the 842 SDGs, sustainable development goals.

843 World Health Organization, 2018. Mortality and burden of disease from ambient air 844 pollution. Available in: http://www.who.int/gho/phe/outdoor_air_pollution/burden/en/. 845 Accessed in August/2018. 